\title{
Carreira outsider: um estudo sobre o processo de rotulação da carreira de músico
}

\author{
Leandro Eduardo Vieira Barros, Mônica Carvalho Alves Cappelle e Paula \\ Guerra
}

\section{RESUMO}

Neste artigo apresenta-se a perspectiva da teoria da rotulação - carreira outsider e seu contexto subjetivo e sua interação social. Portanto, o objetivo foi identificar como ocorre o processo de rotulação da carreira outsider para músicos e quais as implicações sociais e profissionais de se ter uma carreira outsider nos municípios de São João del-Rei e Tiradentes. A abordagem foi qualitativa, com as técnicas de coleta de dados: observação, entrevista com roteiro semiestruturado e técnica projetiva. Os sujeitos foram definidos por acessibilidade e o número de respostas por saturação. Para a análise dos dados, foi utilizada a análise de conteúdo temática. Os resultados apresentam o contexto da microrregião do Campo das Vertentes, a trajetória dos músicos pesquisados, a baixa renumeração, o acúmulo de funções e as dificuldades na gestão da carreira. Nas suas interações sociais, são rotulados pela família, amigos, companheiro(a) e sociedade por exercerem sua carreira, ou seja, é considerada uma carreira com baixo status social. Por fim, são apresentadas as limitações da pesquisa e sugestões para futuros trabalhos.

Palavras-chave: carreira outsider; interacionismo simbólico; músicos.

\section{Outsider career: a study on the labeling process of a musician career}

\section{ABSTRACT}

In this article it is presented the perspective of labeling theory - outsider career and its subjective context and its social interaction. Therefore, the objective was to identify how the outsider career labeling process occurs for musicians and the social and professional implications of having an outsider career in the municipalities of São João del-Rei and Tiradentes. The approach was qualitative, with the following data collection techniques: observation, interview with a semistructured script and projective technique. The subjects were defined by accessibility and the number of responses by saturation. For the data analysis, the thematic content analysis was used. The results presented the context of Campo das Vertentes microregion, the trajectory of the researched musicians, the low income, the accumulation of functions, and the difficulties regarding career management. In their social interactions they were labeled by family, friends, partners, and society because of their career, which meant this was considered a career with low social status. Finally, the research limitations and suggestions for future work were presented.

Keywords: career outsider; symbolic interactionism; musicians.

Recebido em: 27/08/2019 Revisado em: 08/01/2020 Aprovado em: 12/05/2020

Check for updates

\section{Leandro Eduardo Vieira Barros (iD,}

Instituto Federal de Educação, Ciência e Tecnologia do Sudeste de Minas Gerais, São João del-Rei, Brasil Doutorado em Administração pela Universidade Federal de Lavras, Brasil

E-mail: Leandro.barros@ ifsudestemg.edu.br

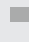

Mônica Carvalho Alves Cappelle (iD,

Universidade Federal de Lavras, Brasil Doutorado em Administração pela Universidade Federal de Minas Gerais, Brasil

E-mail: edmo@ufla.br

Paula Guerra iD,

Universidade do Porto, Portugal Doutora em Sociologia pela Universidade do Porto, Portugal.

E-mail: mariadeguerra@gmail.com 
Introdução

Em termos históricos, o estudo sobre carreiras tem suas origens no século $X X$, em um contexto de etapas e progressão profissional (Chanlat, 1995). Desde então, diversos modelos de carreira foram desenvolvidos. Tolfo (2002) apresenta a carreira tradicional; Schein (1990) a carreira âncora; Arthur (1994) a carreira sem fronteira e Hall (1996) a carreira proteana.

Em geral, esses modelos referem-se ao percurso profissional e à dicotomia entre indivíduo e organização (Closs \& Rocha-De-Oliveira, 2015; Deluca, Rocha-De-Oliveira, \& Chiesa, 2016). Autores como Hughes (1937), Closs e Rocha-de-Oliveira (2015) e Deluca, Rocha-de-Oliveira e Chiesa (2016) criticam essas abordagens no estudo de carreira, devido à falta da dimensão subjetiva a qual leva em consideração a vida do sujeito trabalhador. Tais autores ressaltam ainda a falta de inovação ao estudar a temática e a importância de uma abordagem interdisciplinar.

Khapova e Arthur (2011) corroboram sobre a importância da abordagem interdisciplinar para o estudo acerca de carreiras na sociedade contemporânea, explorando diferentes perspectivas em diversas áreas do conhecimento, como Psicologia, Psicologia Social, Economia, Administração e Sociologia.

Na análise subjetiva e interdisciplinar, sugere-se o interacionismo simbólico, o qual abarca uma dessas perspectivas que transitam entre a Psicologia Social e a Sociologia; trata-se de uma perspectiva teórica e metodológica que pode ser utilizada em estudos na área de Administração, conforme delineado por Mendonça (2002) e Barros, Cappelle \& Guerra (2019).

No entanto, existe uma tensão no campo, segundo Hughes (1937): a concepção subjetiva está em contraposição à tendência da sociedade para o estudo da carreira objetiva e deve ser utilizada na compreensão do conceito de carreira sob uma perspectiva interacionista, a qual se propõe a tratar o indivíduo e sua interação social por meio dos significados e interpretações das ações que ocorrem no contexto social.

Na perspectiva teórica interacionista, encontra-se a Teoria da Rotulação (Labeling Theory) de Howard S. Becker, a qual considera que o indivíduo ou grupo pode ser rotulado como desviante pelos demais membros da sociedade. A interação social ocorre em via de mão dupla no desenvolvimento da carreira do indivíduo e o seu contexto social com o local de trabalho, a família, os amigos, a sociedade e os clientes; entretanto, há aqueles que possuem uma carreira não tradicional em seu contexto social e, por essa razão, são rotulados: esses seriam os outsiders' ${ }^{1}$ Becker, 2008).

A Teoria da Rotulação ressalta que o indivíduo que se desvia das regras sociais do grupo, ou seja, alguém que não vive conforme as regras estipuladas pelo grupo, é considerado um outsider. Nesse sentido, Becker

10 conceito de outsider surgiu no âmbito da Sociologia do Desvio em 1963, com a publicação do livro "Outsiders: studies in the sociology of deviance. Em trabalhos anteriores no Brasil, era comum realizar a tradução de outsiders por "marginais e desviantes", destacando que "desviante" significava, nesse contexto, alguém que está do lado de fora, para além das margens de determinada fronteira ou limite social. Neste trabalho, serão utilizados os dois termos, desviante e outsiders, já que esse último se tornou consagrado nas Ciências Sociais. A edição desse livro consultada foi a versão de 2008. 
(2008, p. 27) definiu o conceito de outsider "para designar aquelas pessoas que são consideradas desviantes por outras, situando-se, por isso, fora do círculo dos membros 'normais' do grupo. O desvio pode ser desenvolvido de forma consciente ou não, ao realizar sua carreira".

Conforme conceito da Sociologia do Desvio, utilizado por Becker (2008) para o estudo sobre carreira, músicos que desenvolvem suas carreiras dentro da lei, da sua cultura e do estilo de vida extravagante e não convencional dentro da comunidade, do grupo e da sociedade em que estão inseridos são rotulados como outsiders, ou seja, desempenham um papel social fora dos padrões considerados normais ou convencionais.

Diante o exposto, a atual pesquisa levanta o problema: a partir da perspectiva de Becker (2008), como ocorre o processo de rotulação da carreira outsider para músicos do gênero sertanejo, que atuam nas cidades de São João del-Rei e Tiradentes, e as implicações sociais e profissionais de se ter uma carreira outsider?

A justificativa, do ponto de vista pragmático, é que os resultados encontrados podem facilitar os músicos no desenvolvimento da sua carreira, bem como a compreensão de sua interação social com familiares, amigos e sociedade, na busca por melhores condições de trabalho e rendimentos mais elevados. Ao mesmo tempo, o trabalho contribuirá com o preenchimento da lacuna existente no campo de estudo sobre carreira, com uma perspectiva interacionista dentro do contexto dos músicos. Dessa forma, a organização do trabalho apresenta alguns padrões e preconceitos relativos à carreira de músico, muitas vezes vividos dentro do seu próprio círculo de amigos e família.

\section{Quadro teórico}

\section{A carreira outsider do músico}

O músico outsider refere-se a uma teoria proposta por Becker (2008) dentro da Sociologia do Desvio, ao tratar da Teoria da Rotulação em estudo sobre a carreira de músico. Nesse processo, um grupo de indivíduos é rotulado de outsider por outros indivíduos em função de um comportamento considerado fora de um padrão "normal" estabelecido no contexto social, dando origem a uma carreira desviante. Dessa forma, o processo de rotulação envolve cinco fases do desvio.

A primeira fase trata de cometer um ato não apropriado, ou seja, a transgressão a um conjunto de regras sociais. O motivo para realização desse ato (no caso carreira desviante) pode ser ou não consciente, influenciado pela subcultura do indivíduo. Essa infração acontece, pois existe uma vontade por parte do indivíduo em ultrapassar os compromissos sociais convencionais, o que influencia a passagem dos atores sociais para a segunda fase, que seria o ingresso em um grupo desviante organizado. Assim, na segunda fase, o indivíduo percebe e aceita o seu desvio, atribuindo-lhe um sentimento de pertencimento e, como consequência, solidifica sua identidade. Nessa fase, o indivíduo aprende uma subcultura organizada em torno da atividade 
desviante. A terceira fase é a descoberta da rotulação social de um ator como outsider. Por fim, o indivíduo cristaliza seu comportamento desviante na forma como a sociedade o trata e como ele se percebe na sociedade e se posiciona. Na quarta fase, o indivíduo, ao ser tratado como desviante, irá "sofrer" a percepção do fracasso social e, na última fase, o ator social, permanecendo na carreira desviante, irá entrar em um grupo social desviante, organizado e estruturado, compartilhando o mesmo destino e problemas da subcultura desviante.

Conforme Miskolci (2005), a obra de Becker marcou uma nova área de estudo do desvio social, ou seja, houve uma mudança em sua pesquisa, saindo da criminalidade e das diligências e passando para as carreiras e o processo de interação social. Segundo Velho (2002), Becker (2008) manteve o propósito da construção e desempenho da ação coletiva por meio da interação dos indivíduos.

Para Lima (2001), Velho (2002) e Miskolci (2005), a Teoria da Rotulação aborda a construção e o desempenho da ação coletiva por meio da interação dos indivíduos e da sociedade nos contextos sociais, em que um indivíduo ou grupo é considerado desviante pelos demais. Conforme Herpin (1982), Lima (2001), Miskolci (2005) e Becker (2008), é relevante considerar aqueles que impõem as normas ou formulam as acusações ao mostrar como tal indivíduo ou grupo vem transgredir essa norma ou de que modo foi rotulado como desviante.

Na perspectiva da Teoria da Rotulação para a compreensão da carreira, o comportamento desviante não tem a necessidade de transgressão da lei; por exemplo, os músicos têm suas atividades dentro da lei, bem como cultura e estilo de vida extravagantes e não convencionais em relação à comunidade em que estão inseridos, sendo, então, rotulados como outsiders. Os músicos são grupos estáveis e duradouros e desenvolvem um estilo de vida próprio, podendo ser definidos como aqueles que tocam música em troca de dinheiro (Becker, 2008). Conforme Guerra (2013) destaca, o sentido de outsider é advém do fato de não se tratarem de características de uma carreira habitual nem de uma profissionalização no sentido clássico do termo.

Quanto às suas condições de trabalho, destacam-se: o trabalho noturno (madrugada) e lugares diferentes, tornando, assim, difícil a participação fora do grupo profissional e a interação social com outras pessoas e com outros grupos sociais (Becker, 2008). Essas características foram encontradas na carreira de músico, dentro do gênero do rock alternativo em Portugal (Guerra, 2013).

Becker (2008) destaca que "as panelinhas" podem promover seus membros, de forma que trabalhadores em posição de nível inferior poderiam participar de trabalhos em nível superior; porém, quem recomenda é responsável pelo desempenho e qualidade; contudo, para se estabelecer no nível superior, é necessário atender às expectativas nos quesitos desempenho e qualidade. No âmbito familiar, Becker (2008) descreve a forte influência da família na escolha da profissão; contudo, muitas vezes, a família é contra a carreira de músico em função do afastamento do comportamento convencional no meio social. Cobranças por parte de familiares desejosos de alguma segurança econômica e de algum comportamento convencional são pressões para o músico abandonar sua profissão. 
Ser músico pode ser considerado como uma carreira outsider, mesmo que esteja ocupando uma posição de status ou reconhecimento, isso em função das características de sua carreira, contexto de trabalho e horários no processo de representação social e identidade de músico.

\section{Papel social e identidade}

O indivíduo, ao desenvolver um comportamento, está exercendo um papel social. Para Vieira, Lima e Pereira (2007), o exercício de papéis sociais é responsável pela integração social e suporte para a constituição da identidade do indivíduo. No desempenho dos papéis sociais, existem aqueles que são considerados coerentes ou adequados por grupos sociais, o que possibilita a interação social. O papel outsider é considerado fora do padrão por um grupo que se denomina normal. Conforme Ciampa (2001), a identidade pode ser entendida como representação de papel social, mas também processo de produção, ou como o próprio processo de identificação.

Papel social e identidade não são sinônimos. O primeiro é estabelecido pelas normas sociais e institucionais, já o segundo é um processo de individualização e é a origem dos significados para os atores sociais (Giddens, 2002). Nesse contexto, "os papéis organizam as funções, enquanto as identidades organizam os significados" (Vieira, Lima, \& Pereira, 2007, p. 31).

Nesse cenário, Dubar (2005) apresenta que identidade pode ter uma noção de dualidade - "identidade para si e a identidade para o outro" (p. 135). Já Goffman (2004) apresenta a identidade virtual como as informações sobre a personalidade do indivíduo e o julgamento dos outros a respeito do indivíduo e identidade real, como os atributos que o indivíduo efetivamente possui e sua percepção de si. Dessa forma, percebe-se uma proximidade da noção de identidade de Dubar (2005) com Goffman (2004). Para Ciampa (2001), se o indivíduo se identifica e é identificado com determinado comportamento, tem-se essa identidade. Nesse caso, a identidade poder ser associada aos tipos de comportamento de Becker (2008).

Portanto, a identidade é construída nos processos de socialização dos indivíduos. A primeira socialização do indivíduo ocorre nos primeiros anos de vida, dentro do espaço familiar ao compartilhar a cultura em que está inserido, na qual aprende comportamentos, valores, regras e visões de mundo. A segunda socialização acontece quando o indivíduo entra em contato com as estruturas sociais, clubes sociais, igrejas, escolas e outros, ao se relacionar com vários indivíduos que detêm características culturais que, em algum momento, diferem das suas (Berger \& Luckmann, 1985).

No processo de identidade do indivíduo, pode-se perceber o atrito entre o comportamento do indivíduo considerado normal e o indivíduo com características outsider no contexto social (Becker, 2008). A identificação do indivíduo com atributos, predicações e comportamentos trata-se do processo de rotulação da identidade que é colocada pela sociedade ou grupo, ou seja, o indivíduo é identificado - "ser-posto" (Ciampa, 2001).

2 Ciampa (2001) trata o "ser-posto" como algo dado, colocado, identifica o indivíduo com determinada identidade. 
Portanto, ao processo de identificação pode ser associado o processo de rotulação, ao descrever o comportamento dos indivíduos como normal ou outsider (Becker, 2008).

\section{- Procedimentos metodológicos}

Esta pesquisa foi desenvolvida em conformidade com as Resoluções n. 466/2012 e n. 510/2016 e aprovada pelo Comitê de Ética, conforme protocolo CAAE 74987317.7.0000.5148, e o Termo de Consentimento e Livre Esclarecido (TCLE), que foi assinado pelos entrevistados.

A abordagem utilizada nesta pesquisa foi a qualitativa. Para coleta de dados, foram utilizadas três técnicas de pesquisas: observação, entrevista de pesquisa biográfica e técnica projetiva. Dessa forma, o uso das três técnicas busca trazer mais detalhes sobre os sujeitos da pesquisa. A observação é uma técnica de coleta de dados em que o pesquisador vê o mundo por meio de suas percepções (Haguette, 2010). Becker (1958) ressalta que é o processo de entrar em contato com o participante e seu ambiente que possibilita uma descrição detalhada das relações sociais e interpretações dos eventos. Para realizar a observação, o pesquisador acompanhou os músicos pesquisados a partir de sua autorização prévia, conforme TCLE. No trabalho de campo, as observações foram anotadas em um editor de texto instalado no celular. Foram realizadas 4 (quatro) observações das apresentações dos músicos em bares e clubes, e 1 (uma) observação foi realizada na reunião da Associação dos Artistas Culturais da Microrregião do Campo das Vertentes. O período de observação foi de 9 de agosto de 2017 até 30 de novembro de 2017.

A entrevista de pesquisa biográfica tem como objetivo compreender a origem do indivíduo, os fatos, as situações, as interações sociais e culturais, as interpretações e sentidos da sua vida do indivíduo (Delory-Momberger, 2012). Essa técnica de coleta de dados busca incorporar a relação do "indivíduo e as representações que ele faz de si próprio e das suas relações com os outros; entre o indivíduo e a dimensão temporal de sua experiência e de sua existência" (Delory-Momberger, 2012, p. 523). Sendo assim, foi elaborado um roteiro semiestruturado, por meio do qual o músico foi convidado a relatar sua trajetória na música através da gravação do áudio.

Após a entrevista de pesquisa biográfica, foi aplicada a técnica projetiva. Foram apresentadas figuras relacionadas à música e solicitado que o respondente associasse a figura com sua carreira de músico, sendo o registro realizado por meio da gravação do áudio. A técnica projetiva de associação de figuras visa registrar percepções e concepções que, normalmente, não são verbalizadas na entrevista em profundidade. Segundo Banks (2009, p. 17), "as imagens são onipresentes na sociedade e, por isso, algum exame de representação visual pode ser potencialmente incluído em todos os estudos de sociedade". 
Os áudios foram transcritos e analisados pela análise de conteúdo temática, conforme delineado por Minayo (2008). Para a análise dos dados, foi utilizada a grade mista: foram inseridas as categorias iniciais e as que sugiram a partir dos dados. As categorias iniciais de análise foram ancoradas no estudo de Becker (2008) e estão relacionadas aos objetivos do artigo, a saber: horários de trabalho, dificuldades financeiras, relacionamentos afetivos e familiares. Já as categorias que surgiram foram: sertanejo feminino, acesso ao crédito, beleza, idade e tecnologia (Vergara, 2015).

Foram pesquisados onze músicos do gênero sertanejo, que têm como principal fonte de renda a carreira de músico nas cidades de São João del-Rei e Tiradentes em Minas Gerais, no período de 4 de outubro de 2017 a 11 de janeiro de 2018. O número de sujeitos da pesquisa respeitou o critério de saturação, pelo qual o aumento de novas entrevistas foi progressivo até quando as entrevistas passassem a não ter aumento significativo de informações (Gil, 1999). Assim, após cada entrevista era feita a sua transcrição, verificadas as novas informações e as respostas aos objetivos da pesquisa. Quando se notou que as entrevistas não apresentavam novas informações e que os objetivos iniciais foram respondidos, optamos por encerrar a coleta de dados.

Além dos músicos, foi entrevistado também um empresário da região e o presidente da Associação dos Artistas Culturais do Campo das Vertentes, totalizando treze sujeitos de pesquisa. A coleta de dados com o empresário e o presidente da Associação objetivou compreender as interações dos músicos nos mais diversos contextos sociais.

\section{Apresentação e análise dos dados}

\section{Perfil dos participantes}

Os músicos pesquisados fazem parte de um contexto de $85 \%$ dos músicos que são autônomos e que têm dificuldades em sobreviver de forma financeira na carreira, conforme salienta Roberto Bueno, presidente da OMB - Conselho Regional de São Paulo, em entrevista ao G1 (2012) (www.g1.com.br). Segundo os dados da OMB - Conselho Regional de Minas Gerais, no estado existe aproximadamente 70.000 músicos, dos quais cerca de 35.000 são registrados. No Quadro 1. Apresenta-se o perfil dos músicos entrevistados. 


\begin{tabular}{|c|c|c|c|c|c|}
\hline Nome $^{3}$ & $\begin{array}{l}\text { Formação na } \\
\text { música }\end{array}$ & $\begin{array}{l}\text { Idade que iniciou } \\
\text { na música }\end{array}$ & $\begin{array}{c}\text { Tempo na carreira } \\
\text { de músico }\end{array}$ & $\begin{array}{c}\text { № de fontes } \\
\text { de renda }\end{array}$ & $\begin{array}{l}\text { Renda em salários } \\
\text { mínimos (SM) }\end{array}$ \\
\hline Paula & Autodidata & 1 ano & De 6 a 10 anos & 2 & De 4 a 10 SM. \\
\hline Fabiano & Autodidata & 17 anos & De 1 a 5 anos & 3 & De 2 a 4 SM. \\
\hline Bruno & Autodidata & 7 anos & Mais de 20 anos & 2 & Até 2 SM. \\
\hline Roberta & Autodidata & 22 anos & Mais de 20 anos & 3 & Até 2 SM. \\
\hline Sergio & Autodidata & 18 anos & Mais de 20 anos & 2 & Até 2 SM. \\
\hline Ronaldo & Autodidata & 15 anos & De 11 a 15 anos & 1 & De 4 a 10 SM \\
\hline Fernando & Autodidata & 11 anos & Mais de 20 anos & 2 & De 2 a 4 SM. \\
\hline Cássia & Autodidata & 17 anos & De 6 a 10 anos & 1 & De 2 a 4 SM. \\
\hline Giovane & Autodidata & 4 anos & Mais de 20 anos & 2 & De 2 a 4 SM. \\
\hline Almir & Autodidata & 7 anos & De 11 a 15 anos & 2 & De 2 a 4 SM. \\
\hline Tiago & $\begin{array}{l}\text { Estudante do curso } \\
\text { superior de música }\end{array}$ & 8 anos & De 11 a 15 anos & 3 & Até 2 SM. \\
\hline
\end{tabular}

Quadro 1. Sujeitos da pesquisa

Fonte: Elaborado pelos autores.

Quanto ao perfil demográfico dos músicos entrevistados, pode-se concluir que a maioria é do sexo masculino, solteiro, com diversidade em relação à faixa etária e sem formação em música, ou seja, autodidatas. Resultados semelhantes foram encontrados na pesquisa de Mendes, Dutra e Pereira (2015). Durante a pesquisa, foi possível observar a forte presença das mulheres na música sertaneja, sendo então uma facilidade encontrar essas profissionais no mercado. Por exemplo, na Associação dos Artistas Culturais da Microrregião do Campo das Vertentes, 14 (quatorze) são mulheres, de um total de 41 associados, o que representa a inserção das mulheres no ambiente da música sertaneja, sendo possível chamar essa vertente de sertanejo feminino.

Os respondentes possuem mais do que uma fonte de renda, com rendimentos em sua maioria é de até 4 (quatro) salários mínimos, provenientes também de outras atividades não relacionadas à música, o que se assemelha aos dados de Poli (2015). Dos músicos com mais de uma fonte de renda, 5 (cinco) trabalham em setores que não são relacionados à música, atuando nos correios, ou como eletricista, desenhista, lojista, ou ainda na Secretaria Municipal de Educação e em fábrica de móveis. Na pesquisa de Guerra (2013), no setor de rock alternativo, foram encontrados resultados semelhantes para o desenvolvimento de atividades paralelas à música.

Assim como no estudo de Pichoneri (2006), os músicos se dedicam a outros tipos de trabalhos não relacionados à música para complementarem a renda. Em situação semelhante, as pesquisas de Côrtes, Benze, Galizia, Côrtes e Reis (2010) e Poli (2015), os músicos pesquisados têm o acúmulo

3 0s nomes dos músicos entrevistados são fictícios e foram escolhidos de forma aleatória.

4 No momento da coleta de dados, o salário mínimo (SM) vigente era $\mathrm{R} \$ 937,00$. Para a faixa salarial, utilizou-se a metodologia do IBGE (Instituto Brasileiro de Geografia e Estatística), na qual até 2 SM é classe E, de 2 SM a 4 SM é classe D e de 4 SM a 10 SM é classe C (IBGE, 2020). 
de funções, fazem a autogestão da sua carreira e o valor da sua remuneração está em conformidade com os dados da Firjan (Federação das Indústrias do Estado do Rio de Janeiro, 2016).

Em relação aos dados funcionais dos músicos, observa-se que a maioria possui mais de 10 (dez) anos de atuação na música. Começaram a aprender música em idade até os 20 (vinte) anos, com média de 12 anos em seu contexto social. O instrumento com maior presença é o violão e o trabalho é realizado em dupla, banda e sozinho. A maioria dos respondentes não é associada à Ordem dos Músicos do Brasil; no entanto, existe um número significativo de pessoas filiadas à associação de São João del-Rei. Os músicos trabalham com carga horária acima de 20 horas semanais e têm que conciliar a agenda de shows, pois o trabalho é concentrado em fins de semana ou feriados.

\section{Contexto da música na microrregião do Campo das Vertentes}

O ambiente social da música faz parte das interações dos músicos pesquisados (Hughes, 1937; Adamson, Doherty, \& Viney, 1998). Ao entender o ambiente social, possibilita-se a compreensão da vida social dos atores sociais envolvidos (Abbott, 1997), ou seja, o contexto situacional da carreira. As cidades São João del-Rei e Tiradentes, em Minas Gerais, são cidades históricas da região das Vertentes. Ambas têm características turísticas, com acervo cultural do período barroco, são próximas geograficamente e possuem uma relação estreita com a música.

Em Tiradentes, existe a Sociedade Orquestra e Banda Ramalho desde o século XIX, com atuação nos dias atuais. Em São João del-Rei, há o conservatório de música, duas orquestras e o curso de graduação de música ofertado pela Universidade Federal de São João del-Rei (UFSJ). No ano de 2015 foi promulgada a Lei Prata da Casa, que trata de incentivo ao artista local. Nesse mesmo ano, foi criada a Associação dos Artistas Culturais da Microrregião do Campo das Vertentes pelos músicos, atores e dançarinos.

\section{A vida de músico: a trajetória dos sujeitos pesquisados}

A carreira pode ser considerada um processo dinâmico, no qual o indivíduo interpreta os significados do contexto e das ações que acontecem em volta de sua vida (Hughes, 1937), interpretando também a sequência dos papéis e as experiências vividas pelos músicos, ou seja, a dimensão subjetiva da carreira (Hughes, 1937; Adamson, Doherty, \& Viney, 1998). Dessa forma, será apresentada a trajetória dos sujeitos pesquisados.

Os músicos entrevistados iniciaram seu contato com a música por meio dos seus pais, familiares, amigos e/ou igreja. Os músicos Bruno, Paula, Cássia, Giovane e Almir tiveram o primeiro contato com os familiares, ou seja, na primeira socialização (Berger \& Luckmann, 1985): o pai ensinando música, o avô sanfoneiro e na família todos são músicos. Oliveira (2011) destaca a influência da família na escolha da carreira e o convívio com a música desde a infância, o que contribui para superar os desafios que surgem ao longo da carreira. Já os músicos Fabiano, Roberta, Sergio, Ronaldo, Fernando e 
Tiago conheceram a música na segunda socialização (Berger \& Luckmann, 1985): amigos, grupos de jovens e igreja. A interação com a família, com os amigos e com a sociedade contribui para a formação e o desenvolvimento da carreira de músico (Dubar, 2005). A partir dos relatos a seguir, percebe-se como os músicos tiveram os contatos iniciais com a música: "Então, desde pequena eu sempre gostei muito de música, né? Meu pai sanfoneiro, meu avô era sanfoneiro..." (Cássia). "Eu comecei a participar do grupo de jovens, ... comecei a tocar na igreja ..." (Sergio).

Observa-se que a música contribui para a inclusão social do indivíduo dentro de um contexto específico: família, amigos, igreja e sociedade, que, de certa forma, influenciaram em suas vidas como um todo. Assim, o espaço social e cultural em que o músico está inserido influencia as suas experiências, as atitudes, a identidade que se forma e está presente na relação do músico com seu ambiente social, ou seja, o músico sofre influência do meio no qual está inserido na relação com a música e no processo de escolha de sua carreira (Abbott, 1997; Centurião, 2003).

Nota-se que o primeiro contato com a música aconteceu em caráter informal, em algum momento da interação social no ambiente em que o indivíduo está inserido, sem intenções de profissionalização, mas em um momento de lazer ou festa (Hughes, 1937; Adamson, Doherty, \& Viney, 1998; Becker, 2008; Guerra, 2018). No entanto, essa atividade, que era considerada um hobby, começa a se tornar uma carreira quando os músicos são convidados para trabalhar em diferentes locais a partir da remuneração dos primeiros cachês, ou seja, um hobby que começa se tornar uma carreira (Oliveira, 2011). Da fala, infere-se, então, o início da profissionalização da carreira: "Quanto que você cobra pra tocar pra mim aqui na minha festa particular? ... Opa! Então, as pessoas, né? Já estão querendo pagar pelo meu talento" (Sergio).

Percebe-se como os músicos começaram a receber os seus primeiros cachês; no entanto, outros músicos, para serem inseridos no mercado, não cobram cachê o que também foi relatado por Bruno e Cássia, que querem apenas divulgar seu trabalho. Em outra situação ocorrida ao acompanhar uma dupla em um bar, conforme o diário de campo do dia 19 de agosto de 2017, durante o intervalo, um músico que estava na plateia solicitou à dupla e ao dono do estabelecimento para apresentar seu trabalho de forma gratuita. Durante 30 minutos, o músico expôs o seu trabalho, na expectativa de receber o convite para tocar de forma remunerada em outra oportunidade no bar ou pela plateia.

Conforme Mendes, Dutra e Pereira (2015) e Poli (2015), no cenário da música quase $50 \%$ dos músicos são autodidatas. Especificamente, os músicos entrevistados Fabiano, Paula, Bruno, Roberta, Sergio, Ronaldo, Fernando, Cássia, Giovane e Almir são, em sua maioria, autodidatas, pois não têm formação teórica, não tiveram aula de canto, aprenderam a profissão no cotidiano (também chamado, popularmente, "de ouvido"). São músicos que não sabem fazer a leitura de partitura; ao utilizar a técnica projetiva com a Figura 1, surgiu o seguinte relato: "Isso aqui eu quis estudar a vida inteira, mas... a partitura, aí que vem a parte do estudo teórico. Eu não tenho teoria nenhuma. Tudo meu foi prática" (Fernando). 


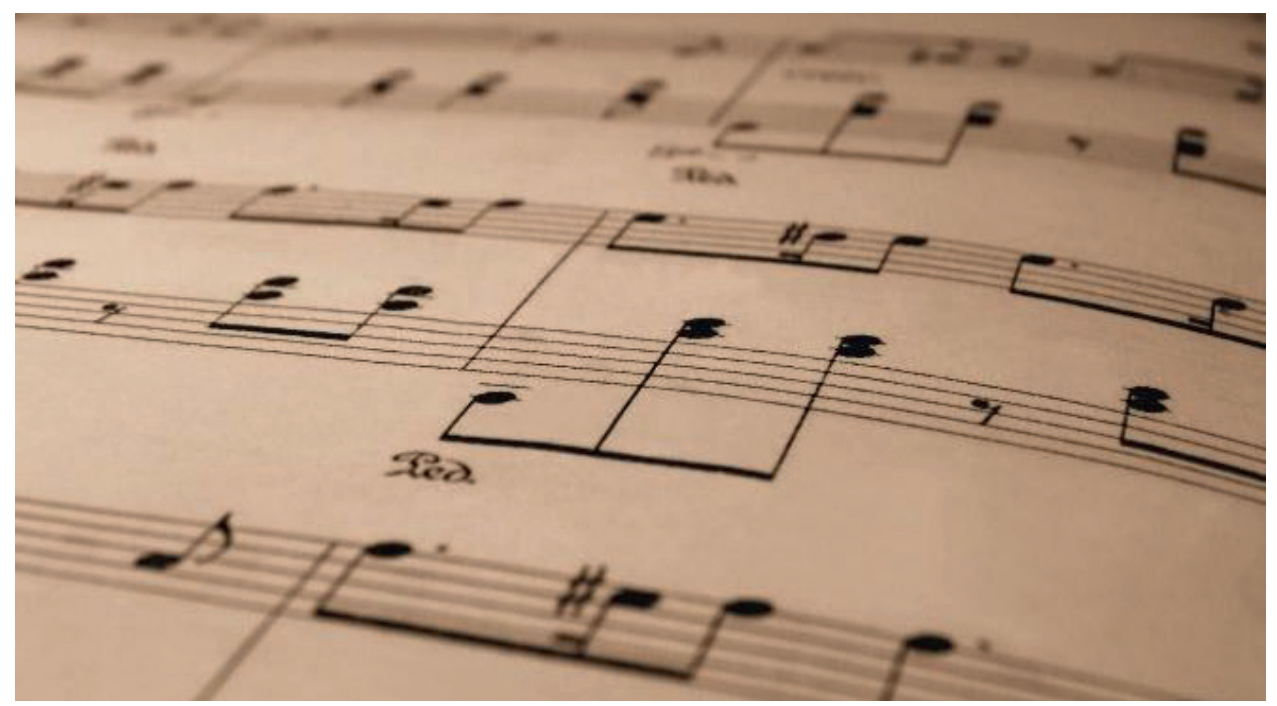

Figura 1. Partitura

Fonte: pt.freeimagens.com.

A respeito da formação do músico, o empresário da região evidencia a falta de formação teórica, de conhecimento da filosofia da música e a falta de estudo. Sobre a formação, os músicos Giovane, Paula e Roberta relatam a importância do estudo e aprendizado. Nessa conjuntura, Oliveira (2011) chama atenção para a qualificação e o aperfeiçoamento da carreira. Na fala a seguir, pode-se notar a necessidade de formação do músico: "O músico tem que estudar! O músico $80 \%$ é ouvido, mas os $20 \%$ é a teoria! ... Quem tem teoria toca música do passado, do presente e do futuro" (Giovane).

Apesar de a maioria dos músicos não possuírem formação musical, no entanto, percebe-se que existe um comprometimento com sua carreira. Os músicos não fazem uso de bebidas antes e durante o show, pois consideram que estão realizando um trabalho e que não é o momento adequado. Essa situação foi verificada em observação em campo. Segundo Oliveira (2011), esse comportamento visa a buscar reputação, credibilidade e uma base de clientes que Ihe traga alguma tranquilidade. Os relatos a seguir retratam essa realidade: "Nada contra quem bebe, mas eu sou do tipo de pessoa que se eu chego numa festa pra trabalhar eu não bebo, entendeu? ... sai um pouco fora do profissionalismo" (Fernando). "É festa! É festa prós outros, né? Não pra ele" (Empresário).

A carreira de músico é percebida pelos músicos respondentes como algo que proporciona sentido à sua vida. Os sentimentos pela música são dom, talento, paixão, fazer o que gosta, sentido para vida, hobby, sentir o prazer em realizar sua carreira. Oliveira (2011) destaca que as principais justificativas para a escolha da carreira de músico são o dom ou o talento, e a identificação pessoal com a carreira. Nota-se que os músicos Ronaldo, Roberta, Fernando, Cássia e Giovane têm a percepção que eles possuem uma carreira vocacional, pois consideram que têm um dom que Deus thes deu, ou seja, uma certa predisposição natural para realizar seu trabalho (Enoque, Borges, \& Borges, 2015). Assim, observa-se a importância da música ao proporcionar diferentes sentidos na vida do músico e reações afetivas positivas (Bastos, 1994). Nos extratos a seguir, pode-se notar o 
sentido que a música proporciona na vida do músico: "...a vida da gente é música" (Cássia). "Na verdade, assim, eu não escolhi, ela que me escolheu" (Fernando). "Eu já nascia... Deus dá o talento pra gente, a gente tem que ir aprimorando" (Ronaldo).

Contudo, o sentimento de fazer parte da música e a música parte da sua vida é o que proporciona sentido à vida deles. A partir da identificação do indivíduo com a música, surge a filosofia de vida, um estilo, uma visão associada à identidade de músico (Hughes, 1937).

Dessa forma, a música é parte das interações sociais e atua na construção social, na formação da identidade (Dubar, 2005) e na transformação dos indivíduos (Ciampa, 2001), nos quais os papéis sociais são desenvolvidos e determinam o pertencimento ao grupo social. Ademais, o papel social desenvolvido pelo músico contribui com sua integração e apoio para construção da sua identidade (Vieira, Lima, \& Pereira, 2007).

O indivíduo, ao viver a carreira de músico, cria uma identidade para si, com suas percepções da carreira - e para os outros - o que pensam a respeito da carreira de músico (Dubar, 2005). Os sentidos que o indivíduo atribui para a música é sua identidade real; já o julgamento de terceiros sobre a personalidade é a identidade virtual (Goffman, 2004). Dessa forma, o músico encara a sua identidade de forma normal, enquanto a sociedade Ihe atribui o rótulo de outsider (Becker, 2008). Assim, a identidade para si (Dubar, 2005), a identidade real (Goffman, 2004) e o comportamento normal (Becker, 2008) fazem parte daquilo que o indivíduo percebe e sente sobre sua identidade; portanto, a identidade para o outro (Dubar, 2005), a identidade virtual (Goffman, 2004) e o comportamento outsider são perspectivas da sociedade que são lançadas sobre o indivíduo em função do julgamento da carreira (Becker, 2008).

Ao fazer a opção de carreira de músico, de forma consciente ou não, o indivíduo está inserido em uma carreira que foge aos padrões considerados "normais" pela sociedade e passa a fazer parte de uma subcultura. A escolha parte do indivíduo em viver algo que ultrapassa os compromissos sociais convencionais. Nesse momento, a música começa a fazer parte da vida, o indivíduo passa pela primeira fase da teoria da rotulação, ou seja, o ingresso em uma carreira com características depreciadas pela sociedade - outsider. Quando o músico percebe e aceita esse processo com sentimento de pertencimento e fortifica sua identidade, ocorre a segunda fase do processo de rotulação da carreira de músico (Becker, 2008).

A partir dos convites para trabalhar como músico de forma remunerada, a maioria começa a perceber tal posição e a fazer investimentos em clipes, CD (disco compacto), equipamentos, iluminação, vídeo no Youtube, página nas redes sociais e lives (transmissão ao vivo), ou seja, um processo de profissionalização e divulgação da carreira. Observa-se que os músicos Fabiano, Paula, Bruno, Roberta, Sergio, Ronaldo, Giovane e Almir possuem um CD gravado para apresentação do seu trabalho, e todos têm páginas em redes sociais, e vídeos no Youtube para o público acompanhar as novidades e agenda de shows (Poli, 2015). De acordo com o relato do músico sobre o processo de investimento nessa carreira: "Porque você ir num programa de televisão é muito caro, véio. E para você postar uma música no Youtube não é nada, entendeu?" (Fabiano). 
As redes sociais têm sido utilizadas pelos músicos entrevistados para divulgar seu trabalho em um processo de autopromoção, uma vez que participar de um programa de televisão é considerado caro pelos músicos (Guerra, 2016). Dessa forma, pode-se afirmar que a tecnologia viabiliza um ambiente de oportunidades, mas também a divulgação do trabalho e de interação entre o músico e seu público. A tecnologia possibilita que aqueles com menor recurso financeiro possam produzir e distribuir sua música, o que não era possível antes da internet, devido à necessidade que havia em se ter contrato com uma gravadora (Côrtes et al., 2010).

Esse é um contexto diferente de Becker (2008), quando realizou seu estudo, pois os músicos não dispunham de redes sociais para fazer a divulgação do seu trabalho; assim, era muito comum o processo de indicação, uma vez que não era possível acompanhar o desenvolvimento do músico como acontece atualmente. Apesar de todos os músicos realizarem sua divulgação em mídias sociais, nem todos possuem essa facilidade e qualidade; portanto, surgem empresas especializadas nesse ramo de divulgação.

Ao utilizar a técnica projetiva, as Figuras 2 e 3 foram apresentadas aos músicos e surgiu o seguinte comentário quanto à sua carreira: "É cansativo, né? Essa questão de passagem de som, de montagem, iluminação, você fica... acho que é a coisa que mais cansa no músico" (Roberta).

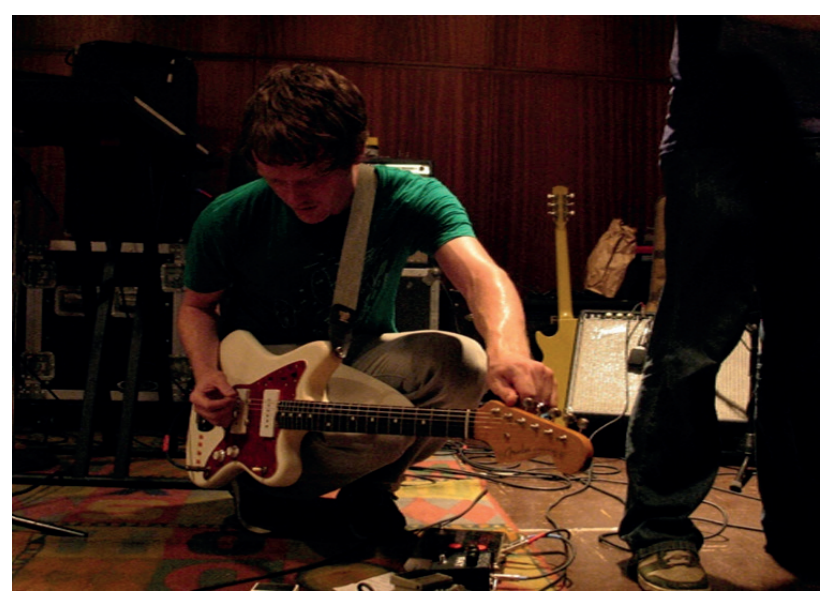

Figura 2. Músico afinado instrumento Fonte: pt.freeimagens.com

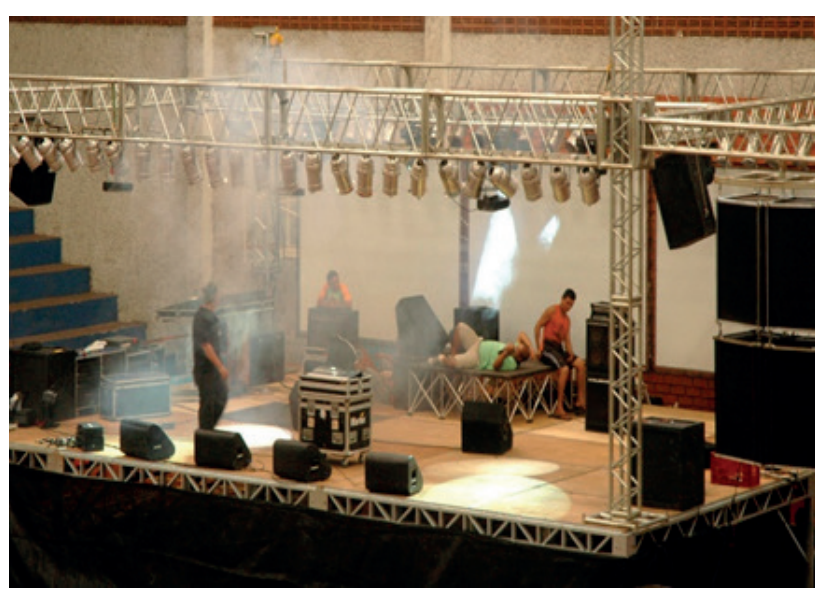

Figura 3. Palco

Fonte: pt.freeimagens.com

Entende-se que a carreira de músico não é apenas o palco, mas o trabalho que envolve desde o ensaio, aprender uma música, a viagem até o local do evento, montagem do som, passagem do som, iluminação, show, desmontagem dos equipamentos e retorno do show. Em função de todas essas atividades, os músicos salientam a necessidade de profissionais para auxiliar em toda essa preparação, que, em si, é cansativa.

O empresário da região destaca as dificuldades vividas pelos músicos. Observa-se que os bastidores da música, muitas vezes, não são percebidos pelo público; dessa forma, surge a ilusão do fã com a carreira de músico, o que encobre suas reais relações e condições de trabalho (Requião, 2016). Esse contexto pode ser associado à música Nos Bailes da Vida, de autoria de 
Brant e Nascimento (1981), que menciona na estrofe "Cantando me disfarço e não me canso de viver nem de cantar", demonstrando que o músico não apresenta para seu público o percurso de preparação.

Em relação à gestão da carreira, Poli (2015) destaca que mais de 60\% dos músicos realizam a sua gestão e fazem outras atividades relacionadas à música. Evans (1996) aponta a necessidade de o indivíduo se tornar autônomo e independente na gestão da sua carreira. Côrtes et al. (2010) evidenciaram que o músico deve desenvolver outras habilidades, em especial na administração para a profissionalização da carreira; porém, muitas vezes, a gestão da carreira não é realizada com profissionalismo em função do despreparo do artista e pela dificuldade em operacionalizar tal gestão, especialmente por não possuir uma formação (Poli, 2015). Esse cenário é apresentado pelos músicos pesquisados que atuam em diferentes setores, como marketing da carreira, divulgação, gestão financeira, motorista, técnico de som, entre outras funções, além de cantar. Além disso, os músicos relataram a dificuldade de fazer a gestão e consideram importante uma equipe para contribuir nessas operações, conforme pode ser observado no relato a seguir:

Na verdade, a gente não tem, a gente não tem um produtor, então a gente tem que fazer tudo, por isso que eu falo quer nós somos profissionais, porque o cantor amador, ele tem que ser cantor, produtor, empresário, motorista, técnico de som (Sergio).

Todos os músicos entrevistados relataram que têm como objetivo o sucesso $^{5}$ na carreira. Para os músicos Fabiano, Roberta, Sergio e Cássia, o sucesso está relacionado com o lançamento de uma música de sucesso, estar na mídia, ter uma produção de palco de qualidade. Fabiano, Roberta e Almir esperam que suas composições alcancem o sucesso. Para Fernando e Tiago o desejo é viver da música com condições dignas de trabalho e remuneração. Assim, a percepção do sucesso está relacionada ao reconhecimento da carreira (Oliveira, 2011). Nos relatos a seguir, pode-se notar esse sonho:

Música sua estourada deve ser... assim... como é que fala, maravilhoso, né? (Roberta).

Eu ainda quero ver uma música minha aí, eu cantando ... Essa música minha do (dupla ${ }^{6}$ ), aqui em São João acho que não tem cem pessoas que sabe que a música é minha, se entendeu (Fabiano).

O sonho com o sucesso na carreira foi evidenciado novamente por todos os músicos e, quando apresentada a Figura 4, surgiram os seguintes relatos: "É onde eu quero chegar um dia. Me apresentar para milhares de pessoas" (Ronaldo). "Então, meu sonho... ter uma estrutura gigante. Meu sonho é isso aqui” (Cássia).

50 conceito de sucesso neste trabalho é tratado a partir das perspectivas dos músicos.

6 Letra escrita pelo músico foi vendida para uma dupla sertaneja. A música foi a mais tocada durante uma semana no ano de 2017. 


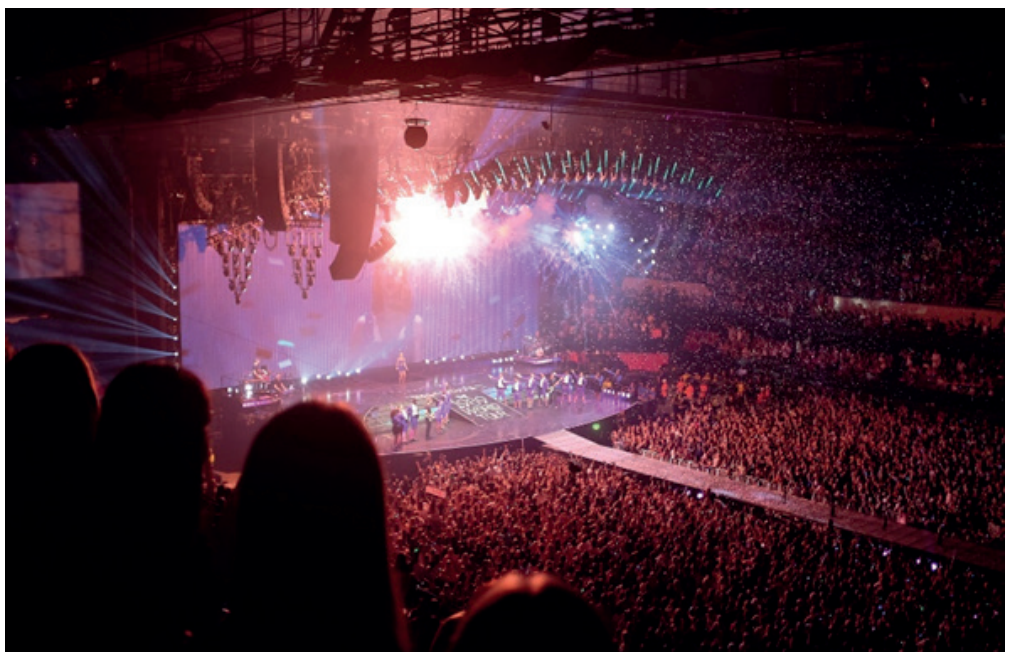

Figura 4. Cenário de interação de um show

Fonte: pt.freeimagens.com

Como afirma Oliveira (2011), o sucesso para o músico está relacionado à fama, sendo essa relacionada a um grande público e apresentação em uma grande estrutura.

Apesar do sonho com o sucesso na carreira, os músicos Bruno, Roberta, Sergio, Fernando, Cássia e Tiago já pensaram em abandoná-la em função das dificuldades para alcançar o sucesso, como a falta de reconhecimento, a "prostituição" do mercado, a dificuldade na divulgação do seu trabalho, a falta de investimento, o desgaste físico (Oliveira, 2011) e mental. Essa situação pode levar a uma baixa satisfação com a carreira e baixo entrincheiramento, que podem ocasionar o abandono da carreira, como relatado por Carson, Phillips e Roe (1996), e Rowe, Bastos e Pinho (2011). Os extratos a seguir ilustram esse contexto:

\section{É a desvalorização! O músico que não está na mídia não é valorizado. Todos aspectos, principalmente o financeiro (Sergio). \\ É o desgaste físico, físico e mental, porque ainda mais no meu caso que, são duas atividades, muita das vezes, assim, é cansativo (Almir).}

Até este momento da carreira de músico, percebe-se que os investimentos são realizados com recursos próprios; no entanto, os músicos Bruno, Roberta, Sergio, Fernando, Giovane, Almir e Tiago comentam que o sucesso em nível nacional está relacionado de forma direta com o alto investimento financeiro, algo que o músico, muitas vezes, não consegue fazer. O que pode ocorrer é o músico encontrar os investidores "padrinhos", que possuem recursos e investem nos músicos. Os relatos a seguir demonstram a necessidade de investimento:

\footnotetext{
O artista hoje em dia tem que buscar um sócio financeiro, né? (Fabiano). O mercado da música ... pra você entrar hoje, tá lá entre os tops, eu acho que você tem que ter grana ou ter alguém que invista em você. É muito caro (Bruno).
}

A cantora Roberta relata em sua experiência a necessidade de investimento financeiro na carreira, a qual chegou a ter contrato com uma gravadora e uma música de trabalho como tema de uma novela de emissora; 
porém, a carreira não continuou em função do término do contrato com a gravadora e a falta de recursos financeiros; assim, o sucesso não atingiu nível nacional.

\begin{abstract}
O segundo CD teve interesse de uma gravadora, o primeiro teve o interesse da pessoa que financiou, né? É (nome do produtor) foi o produtor, né? Mas eu tive uma pessoa que pagou pra essa produção, né? Que foi a... que investiu, ele conseguiu a gravadora, e ela manda lá, né pra pra pras TVs né, ai manda, umas das, umas das músicas teve na novela da (nome da emissora de tv), (nome da novela), (nome da música). Até 2001, a gente teve contrato com a (nome da gravadora) (Roberta).
\end{abstract}

O empresário explica como é o processo de investimentos na carreira de músico. O investidor encontra um músico com potencial para o sucesso, e é realizado um contrato de venda da carreira de músico para o investidor. A partir disso, compra a carreira, investe nela e o músico recebe uma quantia fixa pelo contrato. Em relação ao investimento na carreira, o investidor fica com um percentual dos ganhos do músico. Portanto, nos dois casos existem riscos de o músico não alcançar o sucesso em nível nacional e perder o investimento financeiro. O relato a seguir descreve o exemplo de um cantor que tinha acabado de comprar sua carreira do investidor, além de explicitar como ocorre o processo de investimento no músico:

(Nome do cantor) andava com um violão, de baixo do braço e dava show em... em em, dava show em barzinhos, 150 reais. Um grande produtor viu ele cantar e falou "ah, aquele rapaz é bom", falou pra ele assim "você quer ser meu músico? Te pago 5 mil por mês, procê ser meu músico".

Nessa conjuntura de forte investimento financeiro na carreira, um músico critica o processo de transformação da música em apenas mercadoria, pois pode acabar abrindo mão dos seus objetivos pessoais, sonhos e identidade, em função do interesse do capital, o que denota a marginalização da carreira (Becker, 2008).

Nesse contexto, os músicos destacam que não basta ter talento, mas há a necessidade de infraestrutura, investimento financeiro e conhecer pessoas que possam levar seu trabalho para a grande mídia. Portanto, surgem críticas a alguns músicos que estão fazendo sucesso no mercado, mas não são músicos de qualidade em relação à afinação da voz e talento musical. O sucesso destes ocorre, pois há pessoas investindo em suas carreiras. É relatado o uso da tecnologia para afinar a voz e que existem músicos de qualidade no anonimato; assim, ressalta-se a necessidade de saber se encaixar no mercado e ter uma música que o público goste, mesmo que sem qualidade. Nos relatos a seguir, pode-se notar essa realidade:

A qualidade num tá muito ligado a... ao sucesso, o dinheiro tá (risos) (Roberta).

É inadmissível uma pessoa que não sabe cantar, que é afinada lá no estúdio, afina a voz dela no estúdio pra sair mais ou menos (Fernando). Nosso aquele artista é ruim, mas tem fama, o público gosta (Empresário)

Nesse panorama de investimento financeiro na carreira de músico, Roberta apresenta os valores em cada etapa. Primeiro, é conseguir gravar as músicas em um estúdio de qualidade, fazer um clipe da música - com um investimento entre 6 e 10 mil reais; depois, vem o trabalho de divulgação nas 
rádios, redes sociais; a gravadora distribui em nível nacional - no valor 30 mil por mês durante uns 5 meses.

O empresário da região destacou que para criar condições de um músico ter sucesso, é necessário um investimento entre 3 e 5 milhões de reais; no entanto, não basta ter todas as facilidades, pois a fama é um processo de construção.

Em contraponto às adversidades da carreira, os músicos consideram como facilidade a possibilidade de organizarem seus horários, sua agenda e, principalmente, o prazer em fazer o que gostam. Assim, o músico preza pela sua liberdade de trabalhar e pela satisfação pessoal (Côrtes et al., 2010). Segundo Heslin (2005), esses são alguns dos aspectos da dimensão subjetiva da carreira que são valorizados pelos músicos e, muitas vezes, não são valorizados pela sociedade.

A partir da trajetória apresentada pelos músicos sobre sua carreira e das relações sociais dos músicos, pode-se inferir que o início acontece no dia a dia no processo de interação social; após essa fase, o músico começa a ser conhecido na sua localidade, onde surgem os primeiros convites para trabalho. Depois dos primeiros trabalhos com cachê, o músico observa uma oportunidade de carreira e começa o investimento em melhores instrumentos, gravação de CD e divulgação de seu trabalho. Nessa etapa, observa-se a necessidade de investimentos altos, além de uma boa rede de contatos para distribuição e divulgação do trabalho. No entanto, nem todos conseguem investir grandes quantias na carreira ou um "padrinho"; além disso, existe uma elevada concorrência no mercado; dessa forma, conseguem sucesso em nível de sua cidade ou região. Assim, poucos músicos chegam ao sucesso ou ao reconhecimento no âmbito nacional ou internacional.

\section{As interações sociais dos músicos}

Neste item apresenta-se o componente relacional da carreira de músico; assim, são as interações dos indivíduos com outros atores e seus significados da interação social (Hughes, 1937; Adamson, Doherty, \& Viney, 1998). Dessa forma, busca-se relacionar questões referentes à remuneração, mercado e estilo de música às questões pessoais do músico que podem interferir na sua identidade musical.

Os músicos entrevistados Fabiano, Paula, Bruno Roberta, Sergio, Ronaldo, Fernando, Giovane e Tiago não são associados à Ordem dos Músicos do Brasil (OMB); no entanto, a maioria, Paula, Fabiano, Bruno, Roberta, Sérgio, Fernando e Giovane são associados à Associação dos Artistas Culturais da Microrregião do Campo das Vertentes. Conforme Poli (2014), esse movimento tornou-se comum para os músicos, ao procurarem novas associações em busca de soluções coletivas para o setor. Nesse cenário, percebe-se que a $\mathrm{OMB}$ vem perdendo representatividade e alguns músicos mencionaram que a instituição não contribui em nada. Já a associação, por outro lado, é vista como uma organização que trabalha na defesa dos interesses dos músicos, na divulgação, na inserção no mercado local e melhores condições de trabalho. No entanto, com a entrada em vigor da Portaria n 656, de 22 de agosto de 2018, do Ministério do Trabalho, os 
músicos se viram obrigados a realizar contratos de trabalho e, na celebração do contrato, uma via deve ser enviada a $\mathrm{OMB}$, de forma a proporcionar uma atuação mais efetiva do órgão frente à carreira do músico.

A OMB estabelece uma tabela de valores para os cachês no exercício da carreira; porém, todos os músicos relatam que não seguem a tabela. Em pesquisa realizada por Requião (2016), no Rio de Janeiro, com 312 músicos, mais de 69\% relatam não seguir a tabela do sindicato e mais de $7 \%$ não conhecem a tabela da OMB. Em função de os músicos não conseguirem seguir a tabela da $\mathrm{OMB}$, surgem problemas relacionados à segurança financeira, descontentamento com a remuneração e a necessidade de mais de uma fonte de renda (Assis \& Macêdo, 2010; Poli, 2015; Requião, 2016).

A grande quantidade de músicos na região leva a aumentar a concorrência entres eles por participação no mercado. Isso impulsiona a concorrência em relação aos preços, o que, muitas vezes, pode ser forma desleal ou leilão para quem realiza o trabalho mais barato, deixando a qualidade à parte. Segundo Poli (2013), a concorrência entre os músicos é um problema e a quantidade de contratantes não atende à demanda da classe musical, levando o músico a trabalhar por um cachê menor, ou até mesmo de graça, fatores esses que diminuem os preços e aumentam a oferta no mercado de trabalho. Ocorre, então, a busca por um espaço que seja satisfatório ou de destaque (Oliveira, 2011). Além desse cenário, existem os músicos que se apresentam gratuitamente ou com valor menor para amostra de trabalho e por isso se inserem no mercado, conforme já discutido. Assim, as oportunidades de trabalho podem ser consideradas insatisfatórias (Requião, 2016). Portanto, percebe-se que os músicos que atuam no mercado por hobby e que vendem seu trabalho por valores abaixo do praticado influenciam o preço para os músicos que têm a carreira como um objetivo de vida. Os relatos a seguir demonstram o contexto da concorrência do mercado da música:

O mercado da música tá superlotado... invés de, de ir pela qualidade eles vão pelo preço (Roberta).

Por exemplo, tem muita prostituição musical no mercado (Tiago).

A pessoa que faz só por hobby vai cobrar um preço mínimo, que vai acabar atrapalhando os profissionais que cobram o valor que realmente vale o trabalho (Tiago).

Sobre o estilo de música, nota-se que a sociedade exerce influência no estilo que é apresentado. Essa conjuntura é semelhante ao estudo de Becker (2008), no qual o músico tinha de escolher entre o que o mercado consome e as suas preferências musicais. Essa influência demonstra a fragilidade da carreira e do gênero musical apresentado pelos músicos; assim, as regras são definidas pela sociedade e não pelas preferências do músico. Nos últimos anos, foi ressaltado que o gênero musical rock and roll perdeu espaço para o sertanejo, e o músico teve que se adaptar a essa realidade. Esse cenário é confirmado por Ortega (2017), visto que o sertanejo domina com 74\% das músicas tocadas nas rádios e 40\% nos serviços de streaming ${ }^{7}$.

7 Serviço no qual o cliente paga uma assinatura para ouvir músico, como Spotify e Deezer, por exemplo. 
Quanto à relação dos músicos entrevistados com o contratante, ela é caracterizada pela informalidade, pois a maioria dos contratos são verbais. O empresário da região destaca a importância de que cada músico deve cuidar e desenvolver sua carreira, pois ele apenas contrata quem está mais bem colocado no mercado. Esse contexto pode ser alterado em função da vigência da Portaria n. 656, de 22 de agosto de 2018, e a fiscalização do Ministério do Trabalho (Brasil, 2018). Além disso, há o contratante que ultrapassa o espaço do músico ao subir no palco e utilizar o microfone sem autorização do músico.

No processo de contratação acontece a indicação ou "panelinha" para conseguir trabalho, semelhante ao estudo de Becker (2008). Segundo Poli (2015), é comum a rede de colaboração entre os músicos. A associação pode ser considerada uma rede de colaboração entre os músicos, pois a finalidade é que os músicos associados possam divulgar seu trabalho. Conforme Pichoneri (2006), a rede de contatos influencia no desenvolvimento da carreira; com isso, o músico tem maiores chances de aumentar seus rendimentos e a quantidade de fontes de renda.

$\mathrm{Na}$ interação dos músicos com a plateia, todos relatam possuir uma relação amigável, de forma a buscar atender aos pedidos de músicas da plateia e do contratante, apreciando a interação e participação do público. Situação diferente à apresentada no estudo de Becker (2008), quando os músicos montam barricadas para se distanciarem do público. No entanto, algumas dificuldades podem surgir nessa interação com o público, como pessoas embriagadas e tentativa de assédio sexual. O processo de interação pode ser observado nas falas a seguir:

... porque você enfrenta pessoas que às vezes tão alcoolizadas (Sergio). É um trabalho, e a noite é difícil. O pessoal é muito abusado, não sabe respeitar. ... o cara te achou bonita, aí você desce do palco, ele quer ficar te abraçando, beijando, como se fosse um fã, mas não, ele tá tirando uma casquinha. (Cássia).

No processo de interação com a plateia, os músicos apresentam que o objetivo é levar alegria, felicidade e diversão, pois é o público que faz com que o músico continue sua carreira. Desse modo, é evidenciada a importância da satisfação do público em relação ao trabalho apresentado pelo músico. Para Heslin (2005), são os resultados que a carreira proporciona e que não consideram a remuneração, mas a satisfação, que seria a dimensão subjetiva da carreira.

Em relação à interação, segundo Poli (2015), a tecnologia passou a fazer parte da conjuntura do músico no processo de interação social com o público por meio das redes sociais. Conforme Côrtes et al. (2010), a tecnologia possibilita o aumento de estúdios caseiros para a composição, a gravação de músicas e clipes com baixo custo e boa qualidade, de forma que o músico possa fazer divulgação do seu trabalho e a venda de música; por outro lado, ocorre o aumento o número de downloads ilegais. Nesse cenário, o mercado digital tem influenciado o setor em $70 \%$, de forma que está ocorrendo uma mudança do físico para o digital (Martins \& Slongo, 2014; Poli, 2015; Pro-Música, 2016; IFPI, 2016). 


\section{O processo de rotulação da carreira de músico}

Apresenta-se o processo de rotulação da carreira de músico nos diferentes contextos e por diferentes atores sociais: o comércio, a família do músico, o relacionamento afetivo, a idade, a imagem, o horário, o número de shows, condições de trabalho e, por fim, a rotulação da carreira.

No comércio, os músicos sentem dificuldades em comprar produtos no crediário e sofrem de certa forma uma rotulação pela sociedade da sua condição de profissional autônomo (Assis \& Macêdo, 2010). A falta do emprego formal leva a considerar que a carreira tradicional ainda é muito valorizada no mercado de trabalho, e que a carreira do músico sofre uma marginalização em função das suas características de trabalho e da sua informalidade (Becker, 2008). Desse modo, o indivíduo não é excluído do ambiente social, mas ocupa um lugar de inferioridade. Assim, ocorre a exclusão social por meio de características negativas associadas à carreira de músico (Xiberras, 1993). Frente a esse contexto de informalidade, Bruno relata sua relação com o comércio quando pretendem adquirir algum produto: "Na loja, a pessoa perguntou, e profissão? Eu falei músico, aí a mulher virou na minha cara e falou assim: 'não, mas você não trabalha com outra coisa, não?'”

A percepção da carreira de músico pela família se divide em duas vertentes. A primeira é contra a carreira - no caso, para os músicos Fabiano, Roberta, Sérgio e Cássia. A percepção da carreira do músico é algo que causa decepção na família, pois não é considerada um trabalho; assim, há o julgamento e a rotulação da carreira como algo depreciativo, inferior (Lima, 2001, Becker, 2008). A segunda é o apoio e incentivo - no caso, para músicos Bruno, Paula, Ronaldo, Fernando, Giovane, Almir e Tiago. Nessa, todas as famílias já possuem uma história com a música, ou seja, já estão socializadas e possuem uma identidade com a música (Dubar, 2005; Berger \& Luckmann, 1985), portanto, desejam que o músico continue sua carreira e o incentivam. A seguir, os relatos retratam as duas percepções: "Cara, aqui... pelo menos na minha família não. Porque até uns dois anos atrás o pessoal queria que eu largasse isso e ia trabalhar, entendeu?" (Fabiano). "Senti que meu pai ficava orgulhoso, minha filha tá cantando" (Roberta).

A percepção de algumas(ns) esposas(os) e namoradas(os) sobre a carreira de músico está associada à vida boêmia, uma vez que se pensa que o músico não está trabalhando, mas na "farra" com outras mulheres/ homens. Por isso, quando vão estabelecer uma relação, desejam que o parceiro tenha uma profissão, ou seja, uma segurança financeira. Surgem problemas, como a mulher ficar em casa e o músico sair para trabalhar, o namorado não permitir que a cantora continue sua carreira ou algumas esposas tirarem o marido do mundo da música; são pressões que os músicos sofrem para deixar a carreira. Esses resultados são semelhantes ao do estudo de Becker (2008).

Outro fator que interfere na carreira de músico é a idade, especialmente em relação a conseguir investimento e na qualidade da voz. No caso em questão, a dupla não conseguiu um investidor para sua carreira por serem profissionais 
mais velhos, uma vez que Giovane tinha mais de 41 anos. No estudo realizado por Mendes, Dutra e Pereira (2015), os músicos com mais de 41 anos representam apenas 4\% de um universo de 291 músicos pesquisados. Nesse cenário, Goldani (2010) ressalta que é comum o preconceito e a discriminação em relação à idade na mídia e na sociedade brasileira, de forma a ser um limitador para oportunidades e recursos. Além disso, com o longo tempo de trabalho, surgem problemas relacionados à voz, em função das horas de ensaio, exposição a ambientes barulhentos e poluídos (Barata, 2002). Os relatos a seguir demonstram as duas situações:

\footnotetext{
Mas aí esse amigo rico nosso, tem um outro amigo milionário que gostou de nois pra carai. Gostou muito, foi, queria investir na gente. ... Eu quero investir nesses meninos. Ela falou, olha, eles cantam bem, mas eles já passaram da idade de investimento, já tão velho pra isso (Giovane).

Eu gasto uma grana violenta com fonoaudiólogo que a idade vai chegando a voz vai ficando ruim e como eu tô tocando muitas vezes na semana (Bruno).
}

No ambiente da música, é comum a busca por músicos jovens e com visual atraente. Percebe-se que a música também segue o estereótipo criado pela sociedade em relação aos padrões de beleza. Segundo Sampaio e Ferreira (2009), é um fenômeno contemporâneo em que se valoriza a beleza e há uma busca excessiva para atender aos padrões estabelecidos pela sociedade. No contexto das celebridades, muitos são valorizados por possuírem uma aparência considerada bela, mas sem qualidade e competência. Portanto, pode-se inferir que a música sertaneja busca pessoas com idade mais jovem e com boa aparência. Assim, ocorre a exclusão de parte dos músicos que não atendem aos requisitos de idade e beleza estabelecidos pela sociedade (Xiberras, 1993). Os relatos a seguir demonstram a valorização da beleza: "Eu tô meio desleixada, tô precisando. Risos. ... Fica em dia mais, porque a música cobra, né?” (Roberta). "... hoje todo mundo quer carinha bonitinha, ... quer menino novinho...” (Fernando).

Quanto aos horários de trabalho do músico, observa-se que muitos shows são durante a noite; assim, é comum na parte da manhã o músico estar descansando. Esse cenário é retratado na letra da música "Cada Um Com Seus Problemas", da autoria de João Carreiro (2004), na estrofe "Minha vida é complicada, cantar é meu compromisso, só levanto meio-dia e ninguém tem nada com isso". Na música, é feita uma comparação entre outras carreiras e a carreira de músico, e destaca que é a música é seu compromisso e que seu horário de trabalho é diferente de outras profissões, sendo assim, outras pessoas não devem interferir naquilo que faz.

No dia 21 de outubro de 2017, ao acompanhar uma das cantoras entrevistadas, o show iniciou-se por voltas das 23 horas e terminou por volta das 4h 30 minutos no dia seguinte. Após o show, observou-se a desmontagem da aparelhagem; os músicos chegaram em casa por volta das 5 h 30 minutos do dia seguinte. Situação semelhante foi apresentada por Becker (2008), em relação aos horários de trabalho do músico. Assis e Macêdo (2010) ratificam esse contexto.

Na carreira de músico, é típico ter mais trabalho aos fins de semana; dessa forma, ocorre o acúmulo de trabalho, no qual o músico chega a fazer duas, três ou mais apresentações por noite. No dia 21 de outubro, por exemplo, 
dois músicos da banda se apresentaram à tarde em um barzinho e à noite durante seis horas no show. Assim, é comum a sobrecarga de trabalho, em especial, o músico que exerce mais de uma atividade remunerada (Assis \& Macêdo, 2010). Os estratos a seguir ilustram a sobrecarga de trabalho do músico: "Eu tinha dois shows para fazer, um era seis da tarde numa república e o outro começava nove" (Fabiano). "A gente chega a fazer dois três shows ao dia" (Ronaldo).

Considerando horários e ambiente de trabalho, as condições de trabalho do músico podem ser precárias em função do excesso de repetição de movimentos nos ensaios, exposição a barulho, regulamentação em relação aos direitos trabalhistas para aqueles que a dupla jornada de trabalho é comum (Assis \& Macêdo, 2010; Requião, 2016); no entanto, é flexível em relação aos horários e remuneração (Requião, 2016).

A percepção dos músicos sobre a sua carreira é que a sociedade não considera que eles possuem uma carreira como qualquer outra, mas que estão se divertindo, encaram a mesma como um hobby ou como um momento de lazer - conforme relatado pelo Fabiano que, ao ser convidado para um churrasco, é solicitado que o músico leve o violão para tocar e cantar. Segundo Assis e Macêdo (2010), na sociedade brasileira, a arte não é considerada uma carreira; nesse cenário, Assis e Macêdo (2010) e Oliveira (2011) evidenciaram que os músicos sofrem preconceito em relação à sua carreira e não têm reconhecimento social, sendo, assim, uma carreira marginalizada (Becker, 2008).

Portanto, é comum comentários que depreciam a carreira de músico e a rotulam de forma negativa como: Você não trabalha? Considerando-o como vagabundo, boêmio, mulherengo, que fazem uso de bebida e drogas. Esses fatos demonstram que a carreira de músico sofre uma rotulação pela sociedade por meio da associação com características negativas, ou seja, um processo de designação como outsider (Becker, 2008). Logo, o desvio não parte do indivíduo, mas das características desse tipo de carreira, que pode levá-lo à rotulação por outros indivíduos (Herpin, 1982; Velho, 1985; Centurião, 2003).

Segundo Xiberras (1993), a percepção da sociedade, ao definir o desvio e o olhar do indivíduo rotulado que se relaciona na sociedade conforme sua percepção de mundo, faz parte de dois sistemas de ação que enfrentam representações sociais. Desse modo, o desvio refere-se à ação coletiva, em que as ações e reações dos indivíduos são julgadas no processo de rotulação (Becker, 2008). Os relatos a seguir ilustram o processo de rotulação da carreira:

\begin{abstract}
A maioria das pessoas acha que música não é profissão. ... O músico desde quando a gente sabe, o musico é considerado boêmio (Fernando). Ah o músico é vagabundo, vagabundo que eles falam não é no mau sentido é que cê fica por conta da música, assim como você tá por conta do seu trabalho... ah o vagabundo ele fica o dia inteiro lá por conta da música, não é? Que é vagabundo de malandragem e maldade é fica por conta, só que nós ganhamos esse apelido de vagabundo, e o médico leva o apelido de doutor (grifo nosso) (Giovane).
\end{abstract}

O músico faz uma comparação da sua carreira com uma carreira que possui status na sociedade, evidenciando que sua carreira é rotulada com características negativas, outsider, enquanto a outra carreira é considerada normal e com status social definido (Becker, 2008). 
Os relatos demonstram que o músico tem consciência de que sua carreira é rotulada pela sociedade, ou seja, o músico pode ser considerado um outsider. Assim, o indivíduo mantém seu comportamento, o que é considerado desviante pela sociedade; logo, aqui se encontra a terceira fase do processo de rotulação, isto é, a descoberta de que sua carreira é rotulada (Becker, 2008). O músico considera que está desobedecendo às regras em função do julgamento da carreira tradicional com seu trabalho; assim, é percebido como outsider. Logo, uma identidade é lançada por outras pessoas sobre o músico e os músicos, ao aceitarem essa identidade, se encaixam como desviante puro (Herpin, 1982; Centurião, 2003; Becker, 2008). Em seguida, tem-se a quarta fase do processo de rotulação: a percepção do fracasso quando a carreira de músico é associada a vagabundo, não sendo reconhecida com uma profissão e que ocasiona a falta de acesso ao crédito no comércio por ser um trabalho autônomo (Becker, 2008).

Em relação ao tipo de desvio de comportamento proposto por Becker (2008), o músico se enquadra no desvio puro, o qual é percebido como outsider pela sociedade, reconhece o rótulo e mantém o comportamento de infrator frente às regras consideradas "normais" para uma carreira estabelecida pela sociedade. Segundo Assis e Macêdo (2010, p. 61), "o preconceito social que predomina em relação à atividade musical dificulta o reconhecimento e a identidade de quem proporciona lazer e cultura para a sociedade, a qual valoriza o trabalho formal".

Pelas condições expostas da remuneração do músico, dos valores para se apresentar, e das dificuldades enfrentadas no mercado, pode-se inferir que a carreira possui um baixo status no mercado, o que caracteriza uma desvalorização da carreira. Observa-se que a carreira de músico não possui credibilidade, há falta reconhecimento financeiro e social, não existe uma remuneração mínima e, muitas vezes, os músicos são reféns das regras do mercado em um processo de desvalorização do profissional em que o que interessa é o preço e não a qualidade (Pichoneri, 2011; Becker, 2008; Poli, 2015; Mendes, Dutra, \& Pereira, 2015).

Apesar de a carreira do músico ser rotulada pela sociedade, no entanto, o músico sente-se bem e satisfeito com sua carreira, sendo conscientes das dificuldades, mas "a vida da gente é música", conforme destacado pela Cássia. Segundo Miskolci (2005, p.), "quanto mais ele se engaja, mais ele é implicado e mais difícil se torna renunciar a isso". Assim, na dimensão subjetiva, o sentimento de satisfação em desenvolver a carreira de música faz com que ele permaneça na sua profissão, apesar das características depreciativas que esta possui. Em relação à dimensão objetiva, a carreira não é valorizada em termos de status, remuneração e condições de trabalho. Assim, o insucesso objetivo pode ser equilibrado pelo sucesso subjetivo (Heslin, 2005).

A trajetória da carreira de músico é caracterizada pelos diferentes papéis sociais que o indivíduo desempenha em cada etapa da carreira, sendo um contexto subjetivo e um objetivo, com percepções em um processo dinâmico e de transformação, conforme os papéis desempenhados (Ciampa, 2001). A carreira é marcada desde o primeiro contato com a música e por todas as interações sociais até o presente momento. No processo de interação, o músico entra em contato com diferentes atores sociais que influenciam 
sua carreira e sofrem influência do músico no processo de construção, desconstrução e reconstrução da identidade do indivíduo (Ciampa, 2001; Dubar, 2005).

A Figura 5 foi desenvolvida com o objetivo de sintetizar os estágios da carreira de músicos e suas interações sociais. Os estágios da carreira de músico podem ser divididos em quatro. O primeiro estágio refere-se ao contato com a música por meio da interação social do indivíduo com amigos, família, igreja e sociedade, e afinidade com a música. A partir desse estágio, os músicos iniciam os shows, seja de forma remunerada ou gratuita, para apresentarem seu trabalho. Ocorre que muitos gostam da música e a têm com um lazer. Já os demais começam a observar uma carreira e iniciam os primeiros investimentos em redes sociais, clipes, vídeo na internet, CD e instrumentos. Desse modo, chega-se ao terceiro estágio, o músico se torna um profissional, ou seja, tem como sua principal fonte de renda a sua carreira. No entanto, é relatado que, para ter o sucesso em nível nacional, é necessário forte investimento financeiro, o que não faz parte da realidade da maioria dos músicos. Assim, o investimento pode se tornar um filtro para os músicos terem ou não sucesso. O sucesso é o quarto estágio da carreira; nesse estágio, estão apenas 5\% dos músicos. O fato de o músico não possuir sucesso em termos macro não significa que ele não tenha sucesso em nível regional.

Ao desenvolver a carreira de músico, ele está em contato com o ambiente social, ou seja, esta relaciona-se com diferentes atores sociais e situações para o exercício da carreira. Desse modo, são apresentadas as principais interações destacadas pelos músicos. Nesse processo de interação com sociedade, ocorre o processo de rotulação da carreira por diferentes atores sociais. Os atores, por meio do processo de julgamento, lançam sobre a carreira de músico características que a depreciam e a marginalizam (Becker, 2008).

Assim, na Figura 5 apresenta-se uma proposição dos estágios da carreira de músico e de suas interações sociais.

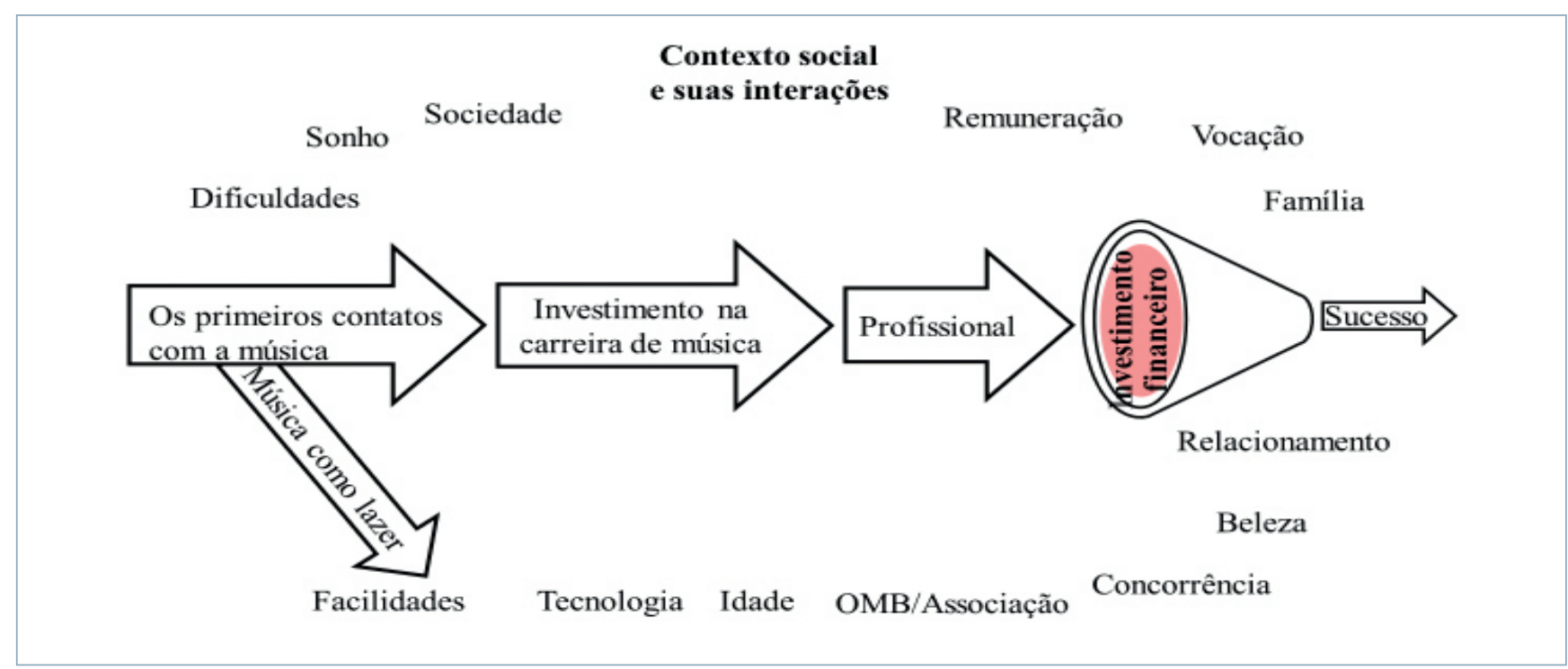

Figura 5. Contexto social e suas interações

Fonte: Elaborada pelos autores. 
Por fim, infere-se a falta de valorização da carreira no mercado em termos financeiros e pela sociedade em relação a prestígio e status; no entanto, o músico considera como facilidade na carreira a possibilidade de organizar sua agenda de trabalho. É destacado que o prazer em realizar a carreira de músico pode ser considerado um fator para o músico enfrentar as dificuldades inerentes à carreira.

Apesar das dificuldades apresentadas pelos músicos, eles continuam na carreira porque a música é algo que proporciona sentido à sua vida, além do prazer em fazer o que gosta e a obtenção da satisfação pessoal. Portanto, devido a esses valores subjetivos da carreira que, muitas vezes, não são reconhecidos pela sociedade, família e amigos, faz com que o músico permaneça na carreira.

\section{Considerações finais}

O objetivo geral neste trabalho foi compreender o processo de rotulação da carreira outsider de músicos, que têm como sua principal fonte de renda esse trabalho nas cidades de São João del-Rei e Tiradentes. Para tanto, foi realizada uma pesquisa qualitativa, na qual os sujeitos de pesquisa foram os músicos. O posicionamento metodológico foi embasado pelo paradigma interpretativo e pensamento sociológico relativo ao interacionismo simbólico. A coleta de dados utilizou três técnicas: a observação, a entrevista de pesquisa biográfica e a técnica projetiva. $\mathrm{Na}$ análise dos dados, foi utilizada a análise de conteúdo temática.

Em relação à família, surgem duas vertentes: a primeira é algo que causa decepção, pois a família não considera a música como uma profissão (Lima, 2001; Becker, 2008). A segunda é o apoio e incentivo, mas, nessa situação, todas as famílias já possuíam uma história com a música, isto é, já estavam socializadas com o contexto da música (Dubar, 2005). Já em relação aos relacionamentos conjugais, estes são marcados pela percepção que o músico está na farra, na vida boêmia, com outros(as) homens/mulheres. E quando vão estabelecer uma relação estável, é comum o músico sofrer pressões para deixar sua carreira (Becker, 2008).

O mercado influencia o estilo musical, de forma que, atualmente, o sertanejo universitário está em destaque, apesar de os músicos tocarem esse estilo, nem todos gostam dele ou encaram como sendo a sua preferência. Esse é marcado pelo excesso de concorrência entre os músicos e algumas vezes até de forma desleal. Quanto ao contratante, essa relação é caracterizada pela informalidade, pois quase todos os contratos são verbais, além de ser identificado o processo de indicação para trabalho. A relação do músico com a plateia é amigável e prazerosa; no entanto, em alguns casos, a plateia extrapola na bebida e no assédio sexual, causando desconforto e desagrado. Em relação à tecnologia, pode-se afirmar que esta passou a fazer parte do cotidiano do músico no processo de gravação, composição, divulgação do trabalho e interação social com o público por meio das redes sociais, permitindo escaparem do poder de influência das grandes empresas de mídia. Quem não está conectado e não interage nas redes perde espaço 
na preferência do público. Assim como profissionais da música de tempos anteriores, os músicos entrevistados também sentem que seu trabalho é levar alegria e sentimento para o público. Já o público constrói uma imagem lúdica da carreira e não percebe e nem reconhece as dificuldades que os músicos enfrentam no dia a dia.

A família dos músicos que não possuía um relacionamento anterior com a música considera que a carreira é uma decepção e que não é um trabalho. Quanto aos relacionamentos afetivos, surgem pressões para que os músicos deixem a carreira e busquem outra que proporcione estabilidade financeira (Becker, 2008). Ademais, a idade do músico é um limitador para oportunidades e recursos (Goldani, 2010). Percebe-se, então, que a carreira na música carrega e reforça o estereótipo criado pela sociedade ao valorizar um profissional jovem de visual bonito (Sampaio \& Ferreira, 2009). No comércio, os músicos enfrentam certa dificuldade em conseguir crediário, pelo fato de a carreira ser autônoma (Assis \& Macedo, 2010). Vale ressaltar que as condições de trabalho podem ser consideradas precárias e de baixa remuneração. A sociedade rotula que a carreira na música não é uma profissão e que, ao praticá-la, o músico está em um momento de lazer e não de trabalho, sendo frequentemente associada à vida boêmia, à procrastinação e à vagabundagem. Nesse contexto, é rotulada e marginalizada pela sociedade (Becker, 2008).

A partir desse estudo, é possível realizar uma associação com o trabalho seminal de Becker, na década de 1960, com músicos de jazz em Chicago, Estados Unidos. Apesar do contexto social, do período, dos atores e do gênero serem diferentes, é possível mapear características que têm aproximações e distanciamento entre os estudos.

Quanto às aproximações das características observadas, têm-se que nos dois estudos permanecem o uso de contatos para conseguir trabalho (panelinhas), uma vez que o mercado influencia o estilo musical, os horários de trabalho são os mesmos (irregulares e noturnos), e a família e os relacionamentos afetivos querem que os músicos deixem a carreira. A insegurança financeira é também um problema apresentado pelos dois grupos de músicos pesquisados.

No que tange aos distanciamentos encontrados, o primeiro refere-se à interação com a plateia, pois os músicos de sertanejo buscam interagir e agradar seu público, enquanto os músicos de jazz montavam barricadas para se manterem distantes da plateia. Outra questão sobre o distanciamento trata-se da tecnologia que não era presente na década de 1960 entre os músicos de jazz pesquisados por Becker. Hoje, a tecnologia faz parte do cotidiano do músico para compor, trabalhar, afinar a voz, divulgar seu trabalho e interagir com o público.

Além disso, no estudo de Becker (2008), foi observado o uso de drogas pelos músicos, pois tratou-se de um estudo em profundidade que utilizou a observação participante e maior e interação do pesquisador com os músicos, pois Becker também era músico de jazz. Neste estudo, por haver diferenças na coleta de dados e na interação entre o pesquisador e os músicos, não será feita nenhuma manifestação sobre o uso ou não uso de drogas. No entanto, é possível verificar notícias em diferentes mídias sobre o uso de 
drogas (lícitas e ilícitas) de músicos do gênero sertanejo ${ }^{8}$. Cabe observar que na música sertaneja, bebidas alcoólicas e principalmente a cachaça, são exaltadas em letras de música e, algumas vezes, utilizadas no palco durante as apresentações. Devido à Pandemia do Covid-19, diversos músicos estão substituindo os shows pela lives e, no caso do estilo sertanejo, tem-se observado em algumas lives o uso excessivo de bebidas alcoólicas pelos músicos, fato que tem sido amplamente criticado pelo público.

Por fim, também foram observadas três novas situações pelas quais os músicos são rotulados: no acesso ao crédito, pois a maioria é autônoma e não possui renda fixa; com relação à imagem (beleza) do músico, pois existe uma influência de um padrão de beleza como estereótipo para sucesso na carreira; e a idade do músico, em que se verificou certo preconceito com músicos mais velhos e a preferência de investimento em músicos jovens.

Por meio da trajetória da carreira de músicos, foi possível mapear as cinco fases do processo de rotulação da carreira de músico propostas por Becker (2008). A primeira fase é o ingresso em carreira considerada outsider de forma consciente ou não; a segunda fase é a interiorização da carreira, na qual o músico percebe e a aceita sua trajetória. A terceira fase é a descoberta de que a carreira é rotulada pela sociedade; a quarta refere-se à percepção de fracasso ao ser considerado vagabundo e não trabalhador; e, por fim, a quinta fase, em que os músicos buscam formas de reduzir os efeitos negativos da rotulação na sua carreira por meio da associação a outros com os quais se identifiquem. A associação dos artistas da microrregião das vertentes é considerada uma organização dos músicos para enfrentar as dificuldades e problemas da carreira. Nesse cenário, o comportamento do músico é o desviante puro, pois a sociedade rotula características negativas à sua carreira e o músico, por sua vez, percebe os aspectos negativos, enfrenta os rótulos, mas continua no exercício da profissão (Becker, 2008).

Diante do contexto de rotulação da carreira de músico, pode-se questionar se ela também não está associada ao retorno financeiro que a carreira proporciona, visto que os músicos que passam a ganhar muito dinheiro e alcançam fama em nível nacional deixam de ser marginalizados. Assim, destaca-se a necessidade de um olhar interseccional à rotulação da carreira, que inclua outras dimensões e aspectos para aumentar a complexidade das análises.

A identidade do músico é, ao mesmo tempo, um processo de individualização e uma forma de reconhecimento social; é a origem dos significados para os atores sociais (Giddens, 2002), e as decisões dos músicos sobre os papéis sociais que representam determinam o pertencimento a determinado grupo e à sua identidade. Assim, o músico pertence ao grupo considerado outsider (Becker, 2008) e se reconhece como membro do grupo, criando uma espécie de identidade coletiva que é capaz de agregar, fortalecer e fazer (re)agir.

8 Por exemplo, 0 cantor Hudson passou pela situação de uso de bebidas alcoólicas, de cigarros e de drogas e o cantor Renner pelo uso de bebida alcoólica (G1, 2014).

9 A live do cantor Gustavo Lima foi criticada pelo uso em excesso de bebidas alcoólicas (Goes, 2020). 
Pode-se concluir, portanto, que existem diferentes identidades para a carreira de músico. Uma identidade é a de "amador", que toca muito em barzinho, que busca o sucesso profissional, e que, além de compor, cantar e tocar, faz a gestão da carreira, a divulgação do trabalho, a negociação, venda e produção do show, monta o palco, entre outras atividades relacionadas à música. Muitos exercem outras atividades remuneradas não relacionadas à música para complementar a renda. Essa identidade é representada por $85 \%$ dos músicos brasileiros, em específico todos os músicos pesquisados. Outra identidade é a dos músicos "de sucesso profissional", com reconhecimento nacional e internacional, que fazem shows em teatros, arenas, estágios e em programas de TV, os quais já contam com uma infraestrutura especializada e com outros profissionais que trabalham no gerenciamento da carreira, divulgação, montagem de palco e outras atividades. Esse grupo é representado por 5\% dos músicos (Moreno 2012). Para se chegar lá, é fundamental um expressivo investimento financeiro e são necessários bons contatos, empresários, beleza e juventude - além de certo talento, é claro.

$\mathrm{Na}$ literatura verificada, apresentam-se três ciclos para a música sertaneja, porém, a partir das observações em campo, das entrevistas e da percepção do mercado, pode-se inferir que existe atualmente um quarto ciclo da música sertaneja. Esse ciclo pode ser caracterizado pelo sertanejo feminino, representado por uma geração de cantoras que seguem o caminho aberto de Inezita Barroso e Roberta Miranda, incorporando o papel de protagonistas nas letras de músicas, bem como na sua interpretação que, na maioria das vezes, combate o machismo arraigado nas músicas tradicionais do estilo sertanejo. Existe um aumento de cantoras do sexo feminino com representatividade no cenário nacional nos últimos anos.

Em função dessa pesquisa ser de caráter qualitativo, os resultados referem-se ao objetivo e aos sujeitos do estudo, o que não permite generalizações; no entanto, o método de pesquisa foi adequado para responder aos objetivos propostos. Porém, sugerem-se novas pesquisas com mais grupos de músicos e com mais carreiras que podem ser consideradas como sendo outsiders, conforme elencadas por Barros et al., (2018) e Barros, Cappelle e Guerra (2019), abordando as dimensões subjetivas (Hughes, 1937; Heslin, 2005; Barros, Cappelle \& Guerra 2019) e objetivas (Hughes, 1937) dessas carreiras e ampliando o número de sujeitos pesquisados, as regiões da pesquisa e diversificando os gêneros musicais. A sugestão é compreender o contexto social no qual o músico está inserido, de forma a aprofundar o estudo sobre os atores sociais, as diferentes situações com que o músico tem contato e cada etapa do processo de formação do músico.

Para os músicos, as sugestões são para ser mais cooperativistas, de forma a diminuir a concorrência entre eles, o que pode levar a uma maior remuneração. Em função de a maioria dos músicos serem autodidatas, sugere-se investigar se a busca de formação pelos músicos pode facilitar o exercício da carreira. Na dimensão subjetiva, pode-se notar que a satisfação com a carreira faz com que o músico enfrente a carreira outsider e permaneça na profissão. Cabe investigar, além disso, se a busca por conhecimento sobre gestão pode facilitar também o processo de gestão da carreira, a venda de shows, o acesso a programas de incentivo, entre outros. 


\section{Agradecimentos}

Ao IF Sudeste MG pelo suporte financeiro. Às sugestões dos pareceristas da RECADM para o aprimoramento deste artigo.

\section{Referências}

Abbott, A. (1997). Of time and space: the contemporary relevance of the Chicago School. Social Forces, 75(4), 1149-1182.

Adamson, S. J., Doherty, N., \& Viney, C. (1998). The meanings of career revisited: implications for theory and practice. British Journal of Management, 9(4), 251-259.

Arthur, M. B. (1994). The boundaryless career: a new perspective for organizational inquiry. Journal of organizational behavior, 15(4), 295-306.

Assis, D.T.F.D., \& Macêdo, K.B. (2010). O trabalho de músicos de uma banda de blues sob o olhar da psicodinâmica do trabalho. Revista Psicologia Organizações e Trabalho, 10(1),52-64.

Banks, M. (2009). Dados visuais. In M. Banks (Coord.). Dados visuais para pesquisa qualitativa (pp.15-34). Porto Alegre: Artmed

Barata, G. (2002). Doenças ocupacionais afetam saúde dos músicos. Ciência e cultura, 54(1), 13.

Barros, L. E. V., Cappelle, M. C. A., \& Guerra, P. (2019). Interacionismo simbólico e carreira outsider: uma perspectiva teórica para o estudo de carreira. READ - Revista Eletrônica de Administração, 25(1), 26-48.

Barros, L. E. V., Cappelle, M. C. A., Souza, R. B. D., \& Lobato, C. B. D. P. (2018). Carreiras outsiders: uma análise a partir da Classificação Brasileira de Ocupações (CBO). Gestão \& Planejamento-G\&P, 19, 121-136.

Bastos, A. V. B. (1994). Comprometimento no trabalho: a estrutura dos vínculos do trabalhador com a organização, a carreira e o sindicato. Tese de Doutorado, Instituto de Psicologia, Universidade de Brasília, Brasília, DF, Brasil.

Becker, H. S. (1958). Problems of inference and proof in participant observation. American Sociological Review, 23(6), 652-660.

Becker, H. S. (2008). Outsiders: estudos de sociologia do desvio. Rio de Janeiro: Zahar.

Berger, P. L., \& Luckmann, T. (1985). A construção social da realidade. São Paulo: Vozes

Brant, F, \& Nascimento, M. (1981). Nos bailes da vida. Intérprete: Milton Nascimento. In M. Nascimento. Caçador de mim. [C.D, Faixa 8].

Brasil. Ministério do Trabalho. Portaria no 656. (2018). Recuperado em 25 setembro, 2018 de http://portal.imprensanacional.gov.br/materia//asset_publisher/ KujrwOTZC2Mb/content/id/37975194/do1-2018-08-23-portaria-n-656-de-22-deagosto-de-2018-37975096

Carson, K.D., Carson, P.P., Phillips, J.S., \& Roe, C.W. (1996). A career entrenchment model: theoretical development and empirical outcomes. Journal of Career Development, 22, 273-286. 
Carreiro, J. (2004). Cada um com seus problemas. Recuperado em 17 outubro, 2018, de https://www.letras.mus.br/joao-carreiro-capataz/1061669/

Centurião, L. R. M. (2003). Identidade e desvio social. Curitiba: Juruá

Chanlat, J. F. (1995). Quais carreiras e para qual sociedade? . Revista de Administração de Empresas, 35(6), 67-75.

Ciampa, A. D. C. (2001). Estória do Severino e a história da Severina, a: um ensaio de psicologia social. São Paulo: Brasiliense.

Closs, L. Q., \& Rocha-de-Oliveira, S. (2015). História de vida e trajetórias profissionais: estudo com executivos brasileiros. Revista de Administração Contemporânea, 19(4), 525-543.

Côrtes, M.R., Benze, R.P., Galizia, F.S., \& Côrtes, F. V. F. R. (2010). O músico empreendedor: novas possibilidades de atuação e novas necessidades de formação profissional em música. Encontro de estudos sobre empreendorismo e gestão de pequenas empresas, 6, 1-9.

Delory-Momberger, C. (2012). Abordagens metodológicas na pesquisa biográfica. Revista Brasileira de Educação, 17(51), 523-536.

DeLuca, G., Rocha-de-Oliveira, S., \& Chiesa, C. D. (2016, jul/ago). Projeto e metamorfose: contribuições de Gillberto Velho para os estudos sobre carreiras. Revista de Administração Contemporânea, 20(4), 458-476.

Dubar, C. (2005). A socialização: construção das identidades sociais e profissionais. São Paulo: Marins Fontes.

Enoque, A. G., Borges, A. F., \& Borges, J. F. (2015). "Além do que se Vê...": Análise do Conceito Weberiano de Vocação à luz da Dinâmica do Empreendedorismo Religioso. Organizações \& Sociedade, 22(75), 505-520.

Evans, P. (1996). Carreira, sucesso e qualidade de vida. Revista de Administração de empresas, 36(3), 14-22.

Federação das Indústrias do Estado Rio de Janeiro. FIRJAN. (2016). Recuperado em 30 janeiro, 2017, de http://www.firjan.com.br/firjan/empresas/competitividadeempresarial/industria-criativa/default.htm

G1. (2014). G1.globo.com. Recuperado em 05 maio, 2020, de http://g1.globo. com/sp/piracicaba-regiao/noticia/2014/12/ano-de-sertanejos-tem-internacao-pordrogas-superacao-morte-e-acidente-hudson-renner.html

Gil, A. C. (1999). Métodos e técnicas de pesquisa social. São Paulo: Atlas.

Giddens, A. (2002). Modernidade e identidade. Rio de Janeiro Zahar.

Goes, T. (2020). Com patrocínio e muita bebedeira, lives de sertanejos dão mau exemplo. Recuperado em 02 de maio, 2020, de https://f5.folha.uol.com.br/colunistas/ tonygoes/2020/04/com-patrocinio-e-muita-bebedeira-lives-de-sertanejos-daomau-exemplo.shtml

Goffman, E. (2004). Estigma: notas sobre a manipulação da identidade. Rio de Janeiro: LTC.

Goldani, A. M. (2010). Desafios do preconceito etário. Educação \& Sociedade, 31(111), 411-434.

Guerra, P. (2013). A instável leveza do rock. Porto: Edições Afrontamento. 
Guerra, P. (2016). Keep it rocking: the social space of Portuguese alternative rock (1980-2010). Journal of Sociology, 52(4), 615-630.

Guerra, P. (2018). Raw power: Punk, DIY and underground cultures as spaces of resistance in contemporary Portugal. Cultural Sociology, 12(2), 241-259.

Haguette, T. M. F. (2010). Metodologias qualitativas na sociologia (12 ed.). Petrópolis: Vozes.

Hall, D. T. (1996). Protean careers of the 21st century. Academy of Management Perspectives, 10(4), 8-16.

Herpin, N. (1982). A sociologia americana: escolas, problemáticas e práticas. Porto: Edições Afrontamento.

Heslin, P. A. (2005). Conceptualizing and evaluating career success. Journal of Organizational Behavior: The International Journal of Industrial, Occupational and Organizational Psychology and Behavior, 26(2), 113-136.

Hughes, E.C. (1937). Institutional office and the person. American Journal of Sociology, 43(3), 404-413.

Instituto Brasileiro de Geografia e Estatística - IBGE (2020). Recuperado em 17 fevereiro, 2020, de https://www.ibge.gov.br/indicadores

International Federation of the Phonographic Industry - IFPI (2016). Recuperado em 30 janeiro, 2017, de http://www.ifpi.org/downloads/Music-Consumer-InsightReport-2016.pdf

Khapova, S. N., \& Arthur, M. B. (2011). Interdisciplinary approaches to contemporary career studies. Human Relations, 64(1), 3-17.

Lima, R. D. C. P. (2001). Sociologia do desvio e interacionismo. Tempo social, 13(1), 185-201.

Martins, J. P. C., \& Slongo, L. A. (2014). O mercado de música digital: um estudo sobre o comportamento do consumidor brasileiro. Revista Brasileira de Gestão de Negócios, 16(53), 638-657.

Mendes, K. A., Dutra, L. M., \& Pereira, D. P. (2015). Relação entre o estudo formal e a média salarial do músico: um estudo com músicos brasileiros. 32, 296-322

Mendonça, J. R. C. (2002). Interacionismo simbólico: uma sugestão metodológica para a pesquisa em administração. Revista Eletrônica de Administração, 8(2), 1-23.

Minayo, M. C. D. S. (2008). O desafio do conhecimento: metodologia de pesquisa social (qualitativa) em saúde. São Paulo: Hucitec.

MISKOLCl, R. (2005) Do desvio às diferenças. Teoria \& pesquisa, 1(47), 9-41.

Moreno, A. C. (2012). Guia de carreiras: música. Recuperado em 25 janeiro, 2017 de http://g1.globo.com/educacao/guia-de-carreiras/noticia/2012/04/guia-decarreiras-musica.html

Oliveira, L. B. (2011). Carreiras "exóticas": o que administradores podem aprender com as vivências de artistas, atletas e outros profissionais. ReCaPe-Revista de Carreiras e Pessoas, 1(2), 1-28

Ortega, R. (2013). Discos mais baratos e curtos, EPs ganham força no mercado do Brasil. Recuperado em 09 março, 2018, de http://g1.globo.com/musica/ noticia/2013/01/discos-mais-baratos-e-curtos-eps-ganham-forca-no-mercado-dobrasil.html?hash=3 
Pichoneri, D. F. M. (2006). Músicos de orquestra: um estudo sobre educação e trabalho no campo das artes. Dissertação de Mestrado, Faculdade de Educação, Universidade Estadual de Campinas, Campinas, SP, Brasil.

Pichoneri, D. F. M. (2011). Relações de trabalho em música: a desestabilização da harmonia. Tese de Doutorado, Faculdade de Educação, Universidade Estadual de Campinas, Campinas, SP, Brasil.

Poli, K. (2013, setembro). O campo da música no contexto das Políticas Culturais. Anais do Siminário Internacional de Políticas Culturais, Rio de Janeiro, RJ, Brasil, 3.

Poli, K. (2014, maio). O setor da música como objeto das políticas culturais federais. Anais do Seminário Internacional de Políticas Culturais, Rio de Janeiro, RJ, Brasil, 4.

Poli, K. (2015, setembro). Economia criativa, política cultural e o trabalho da música - entendendo as relações e descobrindo os agentes. Anais Seminário Internacional de Políticas Culturais, Rio de Janeiro, RJ, Brasil, 6.

Pro-música Brasil Produtores Fonográficos Associados. Pró-música. (2016) Recuperado em 30 janeiro, 2017 de http://www.abpd.org.br/2016/10/24/resumodo-mercado-fonografico-no-1o-semestre-de-2016-e-mudanca-de-nome-da-abpdpara-pro-musica/_

Requião, L. (2016). "Festa acabada, músicos a pé!": um estudo crítico sobre as relações de trabalho de músicos atuantes no estado do Rio de Janeiro. Revista do Instituto de Estudos Brasileiros, (64), 249-274.

Rowe, D. E. O., Bastos, A. V. B., \& Pinho, A. P. M. (2011). Comprometimento e entrincheiramento na carreira: um estudo de suas influências no esforço instrucional do docente do ensino superior. Revista de Administração Contemporânea, 15(6), 973-992.

Sampaio, P. D. A., \& Ferreira, R. F. (2009). Beleza, identidade e mercado. Psicologia em Revista, 15(1), 120-140.

Schein, E. (1990). Career anchors: discovering your real values. San Diego: Pfeiffer \& Company.

Tolfo, S. (2002). A carreira profissional e seus movimentos: revendo conceitos e formas de gestão em tempos de mudanças. Revista Psicologia: Organizações e Trabalho, 2(2), 39-63.

Vergara, S. C. (2015). Métodos de pesquisa em administração. São Paulo: Atlas.

Velho, G. (2002). Becker, Goofman e a Antropologia no Brasil. Sociologia, problemas e práticas, (38), 9-17.

Velho, G. (1985). O estudo do comportamento desviante: a contribuição da antropologia social. Desvio e divergência: uma crítica da patologia social, 6, 11-28.

Vieira, A., Lima, C. H. P., \& Pereira, G. B. (2007). Papéis sociais e expectativas. In A. Vieira \& I. B. Goulart (Coords.). Identidade e Subjetividade na gestão de pessoas. (Vol.1, pp. 27-54). Curitiba: Juruá.

Xiberras, M. (1993). As teorias da exclusão: para a construção do imaginário do desvio. Lisboa: Instituto Piaget. 